\title{
Activities of Amphioxus GH-Like Protein in Osmoregulation: Insight into Origin of Vertebrate GH Family
}

\author{
Mengyang Li, ${ }^{1,2}$ Chengyan Jiang, ${ }^{1,3}$ Yu Zhang, ${ }^{1}$ and Shicui Zhang ${ }^{1}$ \\ ${ }^{1}$ Laboratory for Evolution \& Development, Institute of Evolution \& Marine Biodiversity and Department of Marine Biology, \\ Ocean University of China, Qingdao 266003, China \\ ${ }^{2}$ Institute for Translational Medicine, Qingdao University, Qingdao 266021, China \\ ${ }^{3}$ College of Life Science and Technology, Hong He University, Mengzi, Yunnan 661100, China
}

Correspondence should be addressed to Yu Zhang; yuzhang@ouc.edu.cn and Shicui Zhang; sczhang@ouc.edu.cn

Received 4 October 2016; Accepted 14 November 2016; Published 19 March 2017

Academic Editor: Alexander Schreiber

Copyright (c) 2017 Mengyang Li et al. This is an open access article distributed under the Creative Commons Attribution License, which permits unrestricted use, distribution, and reproduction in any medium, provided the original work is properly cited.

$\mathrm{GH}$ is known to play an important role in both growth promotion and osmoregulation in vertebrates. We have shown that amphioxus possesses a single $\mathrm{GH}$-like hormone $(\mathrm{GHl})$ gene encoding a functional protein capable of promoting growth. However, if GHl can mediate osmoregulation remains open. Here, we demonstrated clearly that GHl increased not only the survival rate of amphioxus but also the muscle moisture under high salinity. Moreover, $\mathrm{GHl}$ induced the expression of both the ion transporter $\mathrm{Na}^{+}-\mathrm{K}^{+}$-ATPase (NKA) and $\mathrm{Na}^{+}-\mathrm{K}^{+}-2 \mathrm{Cl}^{-}$cotransporter (NKCC) in the gill as well as the mediator of GH action IGFl in the hepatic caecum, indicating that GHl fulfills this osmoregulatory activity through the same mechanisms of vertebrate $\mathrm{GH}$. These results together suggest that the osmoregulatory activities of GH had emerged in the basal chordate amphioxus. We also proposed a new model depicting the origin of pituitary hormone family in vertebrates.

\section{Introduction}

Growth hormone (GH) and prolactin (PRL) are structurally related pituitary polypeptide hormones that belong to a superfamily of helical cytokines. Both GH and PRL act by interacting with single transmembrane domain receptors that are also structurally related and belong to the type 1 cytokine receptor superfamily $[1,2]$. These hormones and their receptors are believed to have evolved from common ancestral genes through gene duplication and subsequent divergence early in vertebrate evolution $[3,4]$. However, questions remain about the timing and subsequent elaboration of gene duplication and the elucidation of genetic innovations that may have contributed to the origin and subsequent divergence of pituitary hormones and their receptors in modern vertebrates.

GH and PRL are both multifunctional and share some overlapping biological properties $[4,5]$. For example, they are both known to be involved in the regulation of hydromineral balance in fishes $[6,7]$. GH has been shown to facilitate seawater (SW) adaptation in several fishes including salmonids, tilapia, and killifish [8-11], while PRL shown to be an important freshwater- (FW-) adapting hormone regulating FW adaptation in tilapia and killifish $[12,13]$. GH has been reported to be able to induce the production of ion transporter $\mathrm{Na}^{+}-\mathrm{K}^{+}$-ATPase (NKA) $[11,14,15]$ and $\mathrm{Na}^{+}-\mathrm{K}^{+}-2 \mathrm{Cl}^{-}$cotransporter (NKCC) [16] that provide the driving force for ion-transporting functions of chloride cells in the gills [17-19]. In addition, insulin-like growth factor-I (IGF-I), which mediates many growth-promoting actions of $\mathrm{GH}$, also appears to mediate the osmoregulatory activity of GH during SW acclimation in salmonids $[20,21]$. By contrast, PRL usually maintains plasma homeostasis of fishes in FW by altering salt and water permeability across epithelial cell membranes in the gill, gut, and kidney [22-25].

Amphioxus or lancelet belongs to the subphylum Cephalochordata, an extant representative of the most basal chordates. Recently, we have found that amphioxus possesses a single $\mathrm{GH}$-like hormone $(\mathrm{GHl})$ gene encoding 
a functional protein capable of promoting growth [26]. Moreover, the animal also has a homologue GH/PRLlBP of vertebrate $\mathrm{GH}$-binding protein (GHBP), which is a soluble and truncated form of GHR lacking transmembrane and intercellular parts [26]. However, does GHl, like vertebrate $\mathrm{GH}$, play a role in osmoregulation? And if so, how does it function in amphioxus? The aim of this study is therefore to answer these questions.

\section{Materials and Methods}

2.1. General Experimental Design. In this study, we first injected the amphioxus with recombinant $\mathrm{GHl}$ to test if $\mathrm{GHl}$ plays an osmoregulatory role as vertebrate $\mathrm{GH}$ does. We then explored the osmoregulatory mechanism of $\mathrm{GHl}$. Finally, we investigated if a vertebrate-like GH/IGF axis is also involved in the osmoregulation of amphioxus by examining the correlation of salinity and expression of GHl/IGFl axis genes.

2.2. Animals. Animal experiments were approved by the Ethics Committee of the Laboratory Animal Administration of Shandong Province (permission number SD2007695). All the experiments were performed in accordance with relevant guidelines and regulations. Amphioxus Branchiostoma japonicum with average body length of about $2 \mathrm{~cm}$ were collected from the seashore in Qingdao city, Shandong province, China. They were fed and cultured as described by Wang and Zhang [27].

2.3. Recombinant Proteins. The recombinant protein of amphioxus $\mathrm{GHl}$ ( $\mathrm{rGHl}$ ) was prepared as described by $\mathrm{Li}$ et al. [26]. Zebrafish recombinant GH (rzGH) was purchased from ProSpec (East Brunswick, NJ, USA). The recombinant protein of zebrafish PRL (rzPRL) was produced by the methods of Li et al. [26]. Briefly, the cDNA encoding mature PRL ( 25 to 210 amino acids) was amplified by PCR, and the PCR products were digested with EcorI and XhoI and subcloned into the plasmid expression vector pET28a (Novagen, Germany) cut with the same restriction enzymes. The plasmid constructed was verified by sequencing and transformed into the cells of Escherichia coli BL21 (DE3). The recombinant protein was expressed, purified, and refolded as described by Li et al. [26]. The purified protein was analyzed on a $12 \%$ SDS-PAGE gel and immunostained using anti-His-tag monoclonal antibody (CWBIO, China) as the primary antibody. All the protein concentrations were determined with BCA protein assay kit (Beyotime, China).

2.4. Salinity Tolerance Assay. Salinity tolerance assay was performed to explore if amphioxus GHl, like fish GH or PRL, plays an osmoregulatory role. Pilot experiments showed that when amphioxus was administered with $10 \mu \mathrm{l}$ of saline $(0.9 \% \mathrm{NaCl})$ by intracoelomic injection and cultured in seawater with $38 \%$ or $15 \%$ salinity, $80 \%$ to $100 \%$ mortality was observed at $96 \mathrm{~h}$ after injection (data not shown). Therefore, these salinities were chosen for the following experiments. Amphioxi were first acclimated to $30 \%$ o seawater, and then, 20 animals per group were each injected with either $10 \mu \mathrm{l}$ of saline or $10 \mu \mathrm{l}$ saline containing $10 \mathrm{ng}$
rGHl or $10 \mathrm{ng}$ rzGH or $10 \mathrm{ng}$ rzPRL. The dosages used were according to the previous studies in fishes $[14,16,28]$. Soon after injection, the animals were cultured in $500 \mathrm{ml}$ of seawater with $38 \%$ or $15 \%$ salinity at ambient photoperiod and at room temperature. The salinity was prepared by mixing Millipore ultrapure water with artificial sea salt (Haijia, China). The seawater was changed every $24 \mathrm{~h}$, and the mortality was checked simultaneously. The beating of velar tentacles on the velum can be used as "living marker" of amphioxus; if the tentacles stopped beating, even in response to pricking, then the animals were believed to be "dead."

2.5. Cloning and Expression of $n k a$ and $n k c c . \mathrm{Na}^{+}-\mathrm{K}^{+}$-ATPase (NKA) and $\mathrm{Na}^{+}-\mathrm{K}^{+}-2 \mathrm{Cl}^{-}$cotransporter (NKCC) located in the basolateral membrane of the chloride cells in the gill of fishes are accepted as the major ion transporters [17-19]. Our searching of $B$. floridae genome database (http://genome.jgi-psf.org//Brafl1/Brafl1.home.html) for the homologues of vertebrate NKA and NKCC (using NKA alpha 1 and NKCC1 as queries) revealed the presence of a single NKA (GenBank accession number: XP_002610679.1) and NKCC (GenBank accession number: XP_002609755.1), respectively. We then set to clone $n k a$ and $n k c c$ from B. japonicum. Total RNAs were extracted with Trizol (TaKaRa, Dalian, China) from B. japonicum and digested with RNase-free DNase to eliminate the genomic contamination. The first-strand cDNA was synthesized with reverse transcription system using oligo $\mathrm{d}(\mathrm{T})$ primer. To amplify the fragments of $n k a$ and $n k c c$ cDNAs, polymerase chain reaction (PCR) was performed using the first-strand cDNA as template, in a total volume of $20 \mu \mathrm{l}$ PCR reaction mixture containing $1 \times$ PCR buffer, 0.5 unit of EX Taq DNA polymerase, and $0.4 \mu \mathrm{M}$ of the gene-specific primers P5 and P6 as well as P9 and P10 (Table 1), which were designed on the basis of the putative $n k a$ and $n k c c$ sequences found in B. floridae genome database. PCR was carried out at $94^{\circ} \mathrm{C}$ for $5 \mathrm{~min}$, followed by 34 cycles at $94^{\circ} \mathrm{C}$ for $30 \mathrm{~s}, 54^{\circ} \mathrm{C}$ for $30 \mathrm{~s}, 72^{\circ} \mathrm{C}$ for $1 \mathrm{~min}$, and a final extension step at $72^{\circ} \mathrm{C}$ for $7 \mathrm{~min}$. The PCR products were gel-purified using DNA gel extraction kit (Axygen, Union City, USA), ligated into the T/A cloning vector pGEM-T easy (Promega, Shanghai, China) at $4^{\circ} \mathrm{C}$ overnight, and transformed into the competent cells of E. coli (Tiangen, Beijing, China). The positive clones were selected and sequenced with ABI PRISM 3730 DNA sequencer. The sequences were searched in GenBank with BLASTx for comparative analysis. Sequence comparison against NKA and NKCC was performed by the MegAlign program of the LASERGENE software suit (DNASTAR). Protein domains were analyzed using the SMART program (http://smart.embl-heidelberg.de/).

To examine the expression profiles of $n k a$ and $n k c c$, whole amphioxus and the different tissues including the gill, hindgut, hepatic caecum, notochord, muscle, and skin dissected out of amphioxus were homogenized in Trizol Reagent (Invitrogen) and stored at $-80^{\circ} \mathrm{C}$ until use. Total RNAs extraction and the first-strand cDNA synthesis were performed as above. Semiquantitative RT-PCR (qRT-PCR) was performed using quantified cDNA templates (about 0.3 
TABLe 1: Sequences of the primers used in this study.

\begin{tabular}{|c|c|c|c|}
\hline Gene & Primer & Sequence $\left(5^{\prime}\right.$ to $\left.3^{\prime}\right)$ & Sequence information \\
\hline \multirow{4}{*}{ Zebrafish prl } & P1 (sense) & GAAACCTGTTCTAGTAATGGCTCAAG & \multirow{2}{*}{ cDNA primer } \\
\hline & P2 (antisense) & CTGCGGTCAGAACTTACCTTAGAAT & \\
\hline & P3 (sense) & CCGGAATTCGTGGGTCTGAATGATTTG & \multirow{2}{*}{ Recombinant primer } \\
\hline & P4 (antisense) & CCGCTCGAGCTAGCACATGTCAGGCC & \\
\hline \multirow{4}{*}{ Amphioxus nka } & P5 (sense) & GCTGGCTACAGTGACGGTATGTC & \multirow{2}{*}{ cDNA primer } \\
\hline & P6 (antisense) & CCAGTTCCAGGTAGGCGTTGT & \\
\hline & P7 (sense) & TGCGTAACTTGGAGGCTGTGGAAA & \multirow{2}{*}{ Real-time PCR primer } \\
\hline & P8 (antisense) & GCCAGGTTGGGTTGCTCTTGTCATA & \\
\hline \multirow{4}{*}{ Amphioxus nkcc } & P9 (sense) & CGCCATCGCTCCTCTCATCTCT & \multirow{2}{*}{ cDNA primer } \\
\hline & P10 (antisense) & CTCGGTAGGTCACTTGCTATTGTCAG & \\
\hline & P11 (sense) & TGACTGGGATGGGTAAGATGAGGC & \multirow{2}{*}{ Real-time PCR primer } \\
\hline & P12 (antisense) & TGGTCATTCTGTCTTTCTTGGTCTCG & \\
\hline \multirow{2}{*}{ Amphioxus ef1 $\alpha$} & P13 (sense) & TGCTGATTGTGGCTGCTGGTACTG & \multirow{2}{*}{ Real-time PCR primer } \\
\hline & P14 (antisense) & GGTGTAGGCCAGCAGGGCGTG & \\
\hline \multirow{2}{*}{ Amphioxus gh/prllbp } & P15 (sense) & GAAGACTCGGACCTGGAGACGCACTA & \multirow{2}{*}{ Real-time PCR primer } \\
\hline & P16 (antisense) & CGTGTTCAGGTAGGCGTGGTCGTA & \\
\hline \multirow{2}{*}{ Amphioxus igfl } & P17 (sense) & CTCATCCGCCCATCAGTA & \multirow{2}{*}{ Real-time PCR primer } \\
\hline & P18 (antisense) & GGTTCTTTCTTGTCCGTTT & \\
\hline \multirow{2}{*}{ Amphioxus ghl } & P19 (sense) & CGCTGTTCTTAGACGAGGTTTTGCT & \multirow{2}{*}{ Real-time PCR primer } \\
\hline & P20 (antisense) & CGGTGATGTCAGTAGGCTGGGTG & \\
\hline
\end{tabular}

to $0.4 \mu \mathrm{g} / \mu \mathrm{l})$ and the primers on ABI 7500 real-time PCR system (Applied Biosystems, USA). The PCR primers specific of $n k a$ (P7 and P8), $n k c c$ (P11 and P12), and efla (P13 and P14) were designed using premier 5.0 program [29]. The efla gene was chosen as the reference for internal standardization. SYBR Premix ExTaq ${ }^{\mathrm{TM}}$ (Takara, Japan) was used according to the manufacturer's protocol with a primer concentration of $200 \mathrm{nM}$. The reaction conditions were as follows: $95^{\circ} \mathrm{C}$ for $1 \mathrm{~min}$, followed by 40 cycles of $95^{\circ} \mathrm{C}$ for $5 \mathrm{~s}, 60^{\circ} \mathrm{C}$ for $15 \mathrm{~s}$, and $72^{\circ} \mathrm{C}$ for $35 \mathrm{~s}$. Dissociation analysis was performed at the end of each PCR reaction to confirm the amplification specificity. After the PCR program, the data were analyzed with ABI 7500 SDS software (Applied Biosystems) and quantified with the comparative $\mathrm{Ct}$ method $\left(2^{-\Delta \Delta} \mathrm{Ct}\right)$ based on $\mathrm{Ct}$ values for genes and the reference efla in order to calculate the relative mRNA expression level.

2.6. Assay for Effects of Salinity on Gene Expression and Muscle Moisture. A total of 60 amphioxi was acclimated in the seawater with $25 \%$ o salinity for 15 days and then divided into 2 groups: 30 animals were transferred to seawater with $30 \%$ salinity, and 30 still maintained in seawater with $25 \%$ o salinity. Ten animals were then sampled from each group at 0,48 , and $72 \mathrm{~h}$ after transferring to seawater, and the Hatschek's pit, gill, and hepatic caecum were dissected out of the animals and homogenized in Trizol. The preparation of total RNAs and the expression of both $n k a$ and $n k c c$ in the gill and $g h l$ in the Hatschek's pit and gill as well as $g h / p r l l b p$ and igfl in the hepatic caecum and gill were performed as described above. The collection of the
Hatschek's pit was carried out as described by Fang and Wang [30]. The wheel organ on the right side of the notochord was the part with Hatschek's pit and was dissected out under microscope. The PCR primers specific of $n k a$ (P7 and P8) and $n k c c$ (P11 and P12) were as above, and the primers specific of gh/prllbp (P15 and P16), igfl (P17 and P18), and ghl (P19 and P20) were designed using premier 5.0 program.

The muscle was also dissected out of the animals sampled. The tissue was cut into pieces $1 \mathrm{~mm}^{3}$, dried on filter paper, and soon transferred to $1.5 \mathrm{ml}$ Eppendorf tubes. The muscle moisture was measured as described by Mccormick [28] and Breves et al. [31]. Briefly, $100 \mathrm{mg}$ of the muscle from each group was dried to a constant weight at $60^{\circ} \mathrm{C}$, and the water content was then measured gravimetrically.

2.7. Assay for Effects of $r G H l$ and $r z G H$ on Gene Expression In Vitro. The gill and hepatic caecum were dissected out of amphioxus, cut into pieces $\left(\sim 1 \mathrm{~mm}^{3}\right)$, and cultured in MEM medium containing $2.2 \mathrm{mg} / \mathrm{ml} \mathrm{NaHCO}, 100 \mathrm{IU} / \mathrm{ml}$ penicillin, $100 \mu \mathrm{g} / \mathrm{ml}$ streptomycin, and different concentrations of $\mathrm{rGHl}$ or $\mathrm{rzGH}(0,10,100$, and $1000 \mathrm{ng} / \mathrm{ml})$ at $25^{\circ} \mathrm{C}$. After $4 \mathrm{~h}$ culture, the tissue pieces of the gill and hepatic caecum were pooled and homogenized immediately in Trizol Reagent, and total RNAs were prepared. The expressions of $n k a$ and $n k c c$ in the gill as well as $g h / p r l l b p$ and igfl in the gill and hepatic caecum were analyzed by qRT-PCR as above.

2.8. Assay for Effects of $r G H l$ and $r z G H$ on Gene Expression In Vivo. A total of 90 amphioxi was divided into 3 groups 


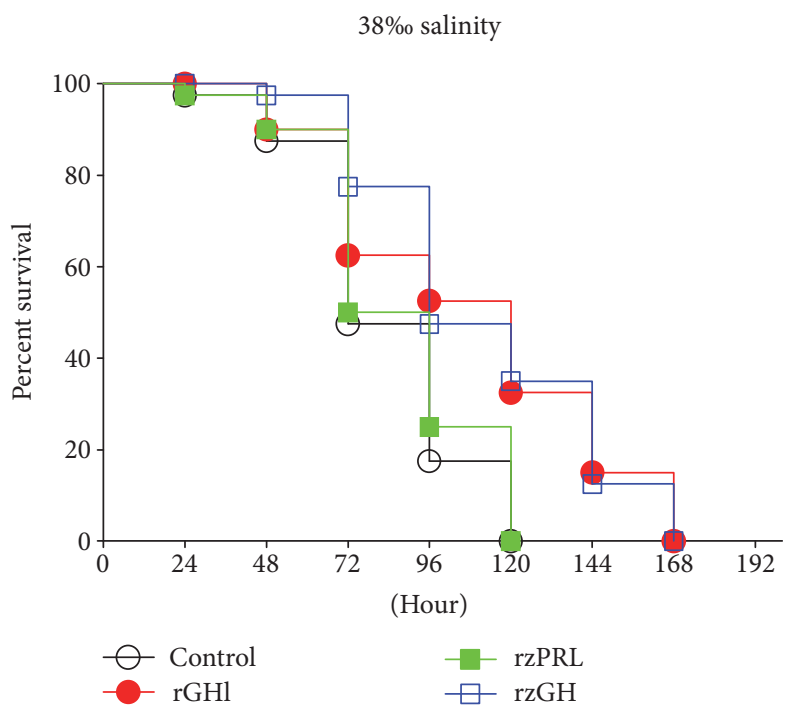

(a)

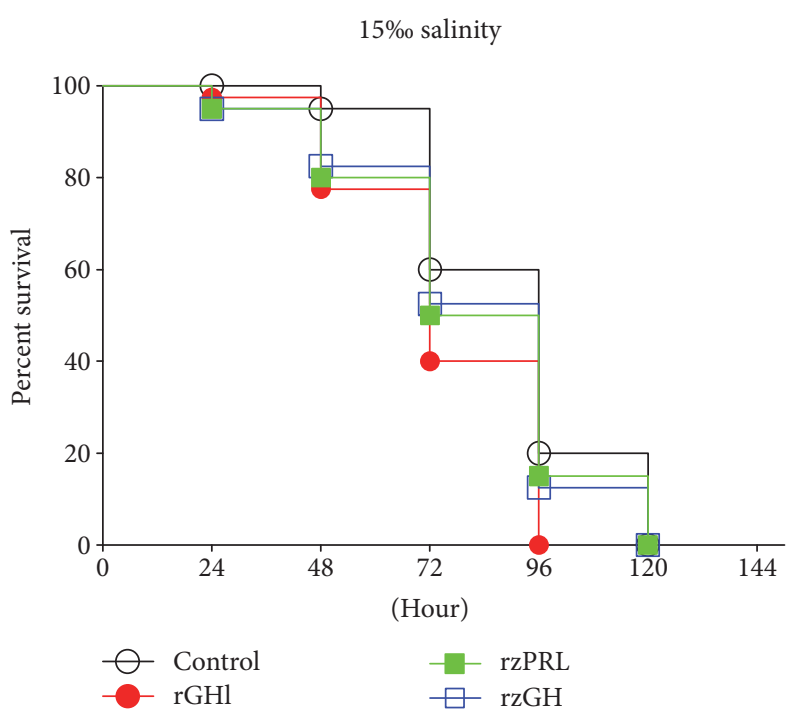

(b)

Figure 1: The survival rates of amphioxus. The animals were injected with saline, rGHl, rzGH, or rzPRL by intracoelomic injection, followed by culture in seawater with $38 \%$ salinity (a) or $15 \%$ salinity (b). Survival was recorded every 24 h. Data are from two independent experiments.

(30/group), and each animal was injected with either $10 \mu \mathrm{l}$ of saline or $10 \mu \mathrm{l}$ saline plus $10 \mathrm{ng} \mathrm{rGHl}$ or $10 \mathrm{ng} \mathrm{rzGH}$. They were then cultured in $500 \mathrm{ml}$ natural seawater and fed once a day with the single-cell alga Spirulina sp. Ten amphioxi were sampled from each group at 0,24 , and $48 \mathrm{~h}$ after injection, respectively, and the gill and hepatic caecum were dissected out of the animals. Both the tissues were homogenized in Trizol, and total RNAs were prepared. The expressions of $n k a$ and $n k c c$ in the gill as well as gh/prllbp and igfl in the gill and hepatic caecum were analyzed by qRT-PCR as above.

2.9. Assay for Effects of $r G H l$ and $r z G H$ on NKA Activity and Muscle Moisture. A total of 90 amphioxi was divided into 3 groups (30/group), and each animal was injected with either $10 \mu \mathrm{l}$ of saline or $10 \mu \mathrm{l}$ saline plus $10 \mathrm{ng} \mathrm{rGHl}$ or $10 \mathrm{ng} \mathrm{rzGH}$. They were cultured and sampled as above. Both the gill and muscle were dissected out of the animals sampled. The tissues were cut into pieces $1 \mathrm{~mm}^{3}$, dried on filter paper, and soon transferred to precooled $1.5 \mathrm{ml}$ Eppendorf tubes. The NKA activity in the gill (ca. $50 \mathrm{mg}$ per group) was analyzed with NKA activity kit (Solarbio, Beijing) as described as Zeng et al. [32]. One unit of enzymatic activity was defined as $1 \mu$ mole ADP released per hour. The muscle moisture was measured as described above.

2.10. Statistical Analysis. Salinity tolerance experiment was repeated twice, while all the other experiments were performed in triplicate and repeated three times. The survival curve was generated by GraphPad Prism 5. The data of the experiments of effects of salinity on gene expression and muscle moisture were analyzed by two-way ANOVA, while the other data analyzed by one-way ANOVA. The difference at $p<0.05$ was considered significant. All the data were expressed as mean \pm SEM.

\section{Results}

3.1. $r$ GHl Enhances Salinity Tolerance of Amphioxus. Recombinant amphioxus $\mathrm{GH}$-like protein $\mathrm{rGHl}$ was expressed and purified as described by Li et al. [26]. Recombinant zebrafish prolactin rzPRL with His tag was expressed in E. coli and purified by chromatography on a Ni-NTA resin column. rzPRL was subjected to SDS-PAGE, which yielded a single band corresponding to the expected sizes of $\sim 24.6 \mathrm{kDa}$. Western blotting revealed that rzPRL reacted with rabbit anti-His-tag antibody, indicating that rzPRL was correctly expressed (see Supplementary Figure 1 in Supplementary Material available online at https://doi.org/10.1155/2017/ 9538685).

Figure 1 shows the survival rates of amphioxus injected with saline, $\mathrm{rGHl}, \mathrm{rzGH}$, or rzPRL, followed by culture in seawater with different salinity. The culture under high salinity $(38 \%)$ resulted in $52.5 \%, 82.5 \%$, and $100 \%$ as well as $50 \%, 75 \%$ and $100 \%$ cumulative mortality, respectively, in the saline- and rzPRL-injected amphioxus at 72, 96, and $120 \mathrm{~h}$ after injection. The mortalities of these two groups were not statistically different. The same culture caused only $37.5 \%, 48.5 \%$, and $67.5 \%$ as well as $22.5 \%, 52.5 \%$, and $65 \%$ cumulative mortality, separately, in the rGHl- and rzGH-injected animals at the same experimental periods. The survival rates of the rGHl- and rzGH-injected groups were significantly higher than control (Figure 1(a)). By contrast, the culture under low salinity (15\%o) resulted in $40 \%$ and $80 \%, 60 \%$ and $100 \%$, and $47.5 \%$ and $87.5 \%$ as well as $50 \%$ and $85 \%$ cumulative mortality, individually, in the saline-, rGHl-, rzGH-, and rzPRL-injected animals at 72 


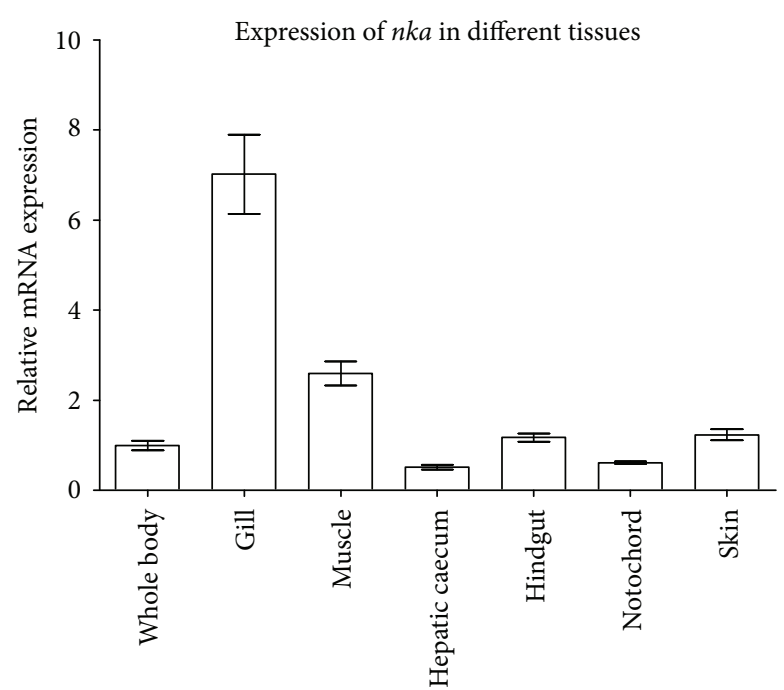

(a)

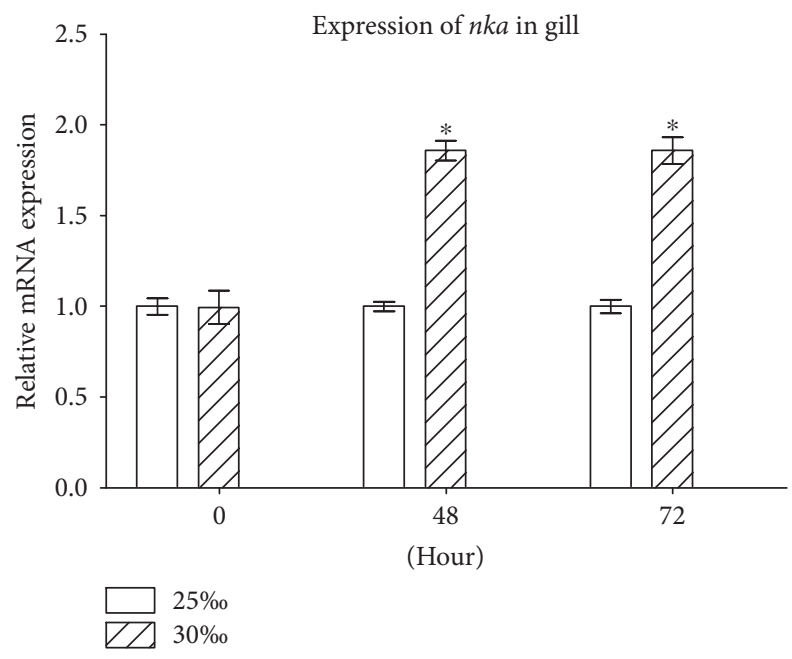

(c)

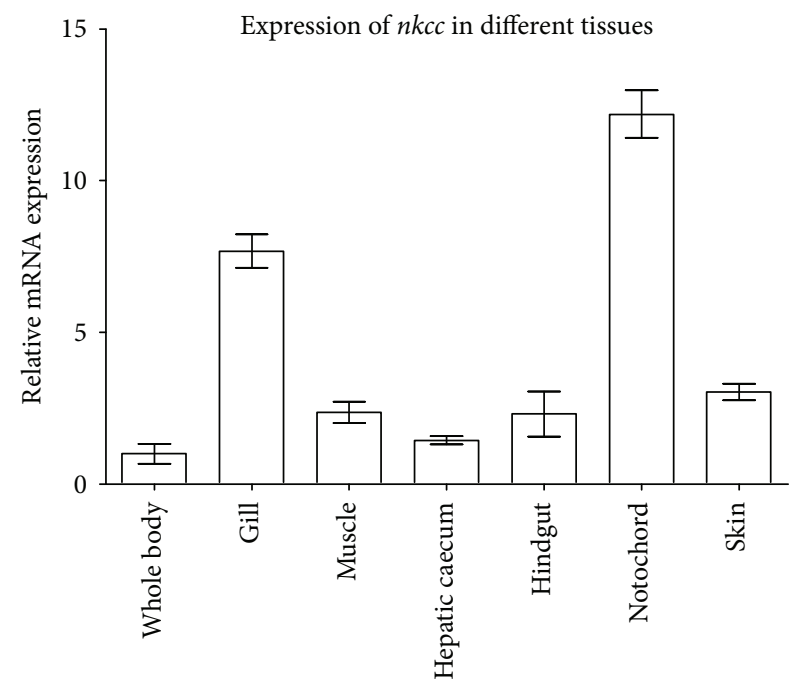

(b)

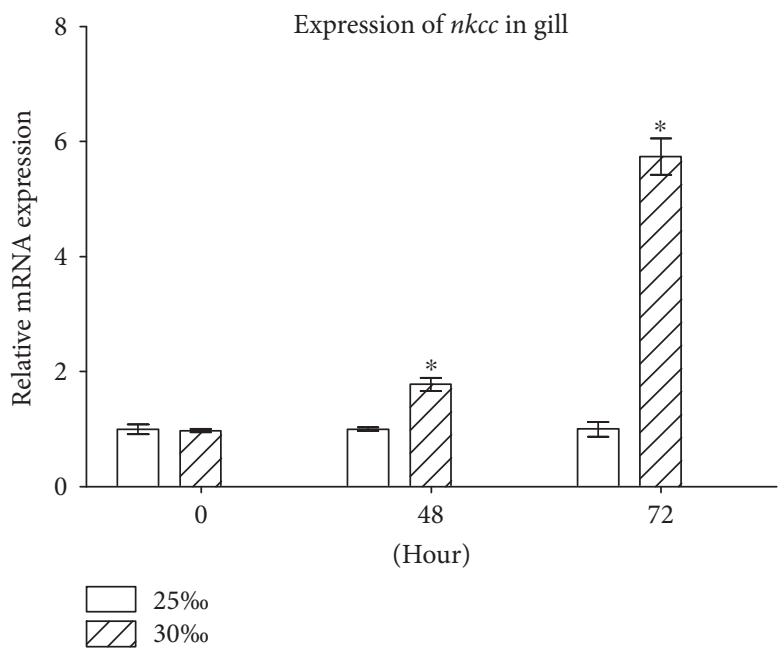

(d)

FIGURE 2: Identification of $n k a$ and $n k c c$. (a) The expression profiles of $n k a$ in the different tissues including the gill, hindgut, hepatic caecum, skin, notochord, and muscle. (b) The expression profiles of $n k c c$ in the different tissues. (c) Expression of $n k a$ in the gill of amphioxus cultured under $25 \%$ or $30 \%$ salinity. (d) Expression of $n k c c$ in the gill of amphioxus cultured under $25 \%$ or $30 \%$ salinity. The efl $\alpha$ was chosen as internal control for normalization. Data were from 3 independent experiments and expressed as mean \pm SEM. The symbol $*$ shows $p<0.05$.

and $96 \mathrm{~h}$ after injection, and none of the animals survived by $120 \mathrm{~h}$. No statistical difference was observed in the groups (Figure 1(b)). These data together indicated that amphioxus $\mathrm{GHl}$, like zebrafish $\mathrm{GH}$, could promote salinity tolerance of amphioxus, but zebrafish PRL could not.

3.2. $r G H l$ Induces Expression of $n k a$ and $n k c c$. Partial cloning revealed the presence of $n k a$ and $n k c c$ in amphioxus that are highly identical to their counterparts in fish and mammalian species. Specifically, the $n k a$ cDNA fragment (GenBank accession number: KU312041) we cloned from B. japonicum was $629 \mathrm{bp}$ long, encoding a deduced peptide of 209 amino acids which has $78.9 \%$ to $80.4 \%$ identity with vertebrate NKA3, and a cation_ATPase domain characteristic of NKA, and the $n k c c$ cDNA fragment (GenBank accession number: KU312042) obtained was 960 bp long, coding for a deduced NKCC-like peptide of 319 amino acids, which possesses $45.8 \%$ to $48.3 \%$ identity with vertebrate NKCC1, and both AA_permease and SLC12 domains typical of NKCC (Supplementary Figures 2 and 3 ). As shown in Figures 2(a) and 2(b), both $n k a$ and $n k c c$ displayed a tissue-specific expression, with relatively abundant levels in the gill. The gene $n k c c$ was also abundantly expressed in the notochord. To test if salinity change affects the expression of $n k a$ and $n k c c$ in the gill, the $25 \%$ o salinityacclimated animals were transferred to seawater with $30 \%$ salinity, and the expression of $n k a$ and $n k c c$ in the gill was analyzed. No dead animals were observed. As shown in Figures 2(c) and 2(d), the transfer of 25\%o salinity-acclimated amphioxus to seawater with $30 \%$ 


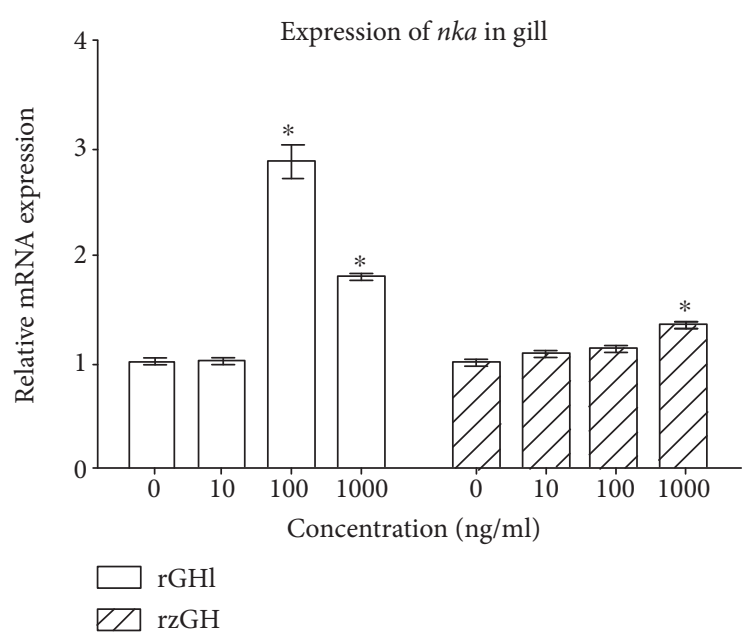

(a)

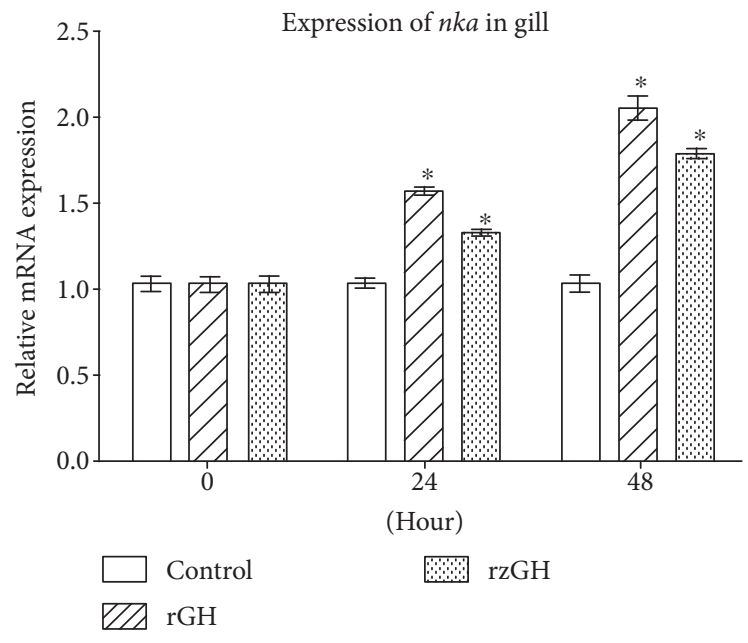

(c)

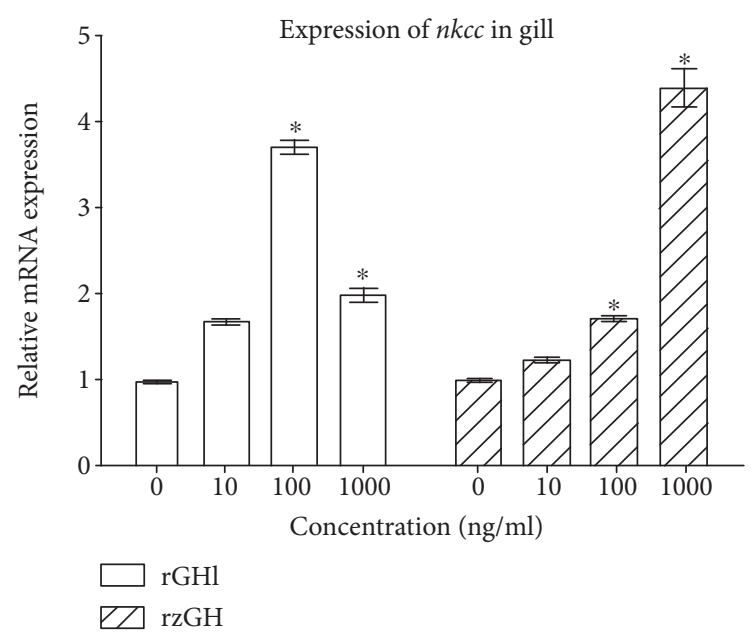

(b)

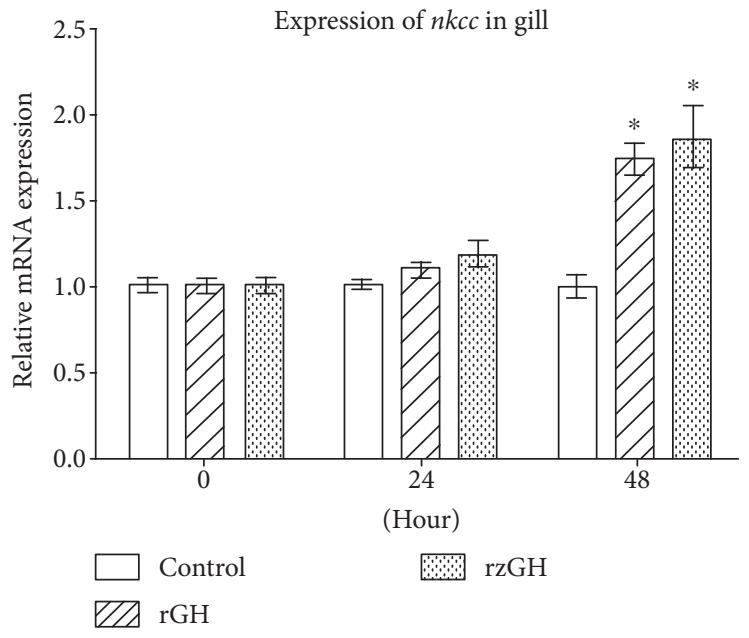

(d)

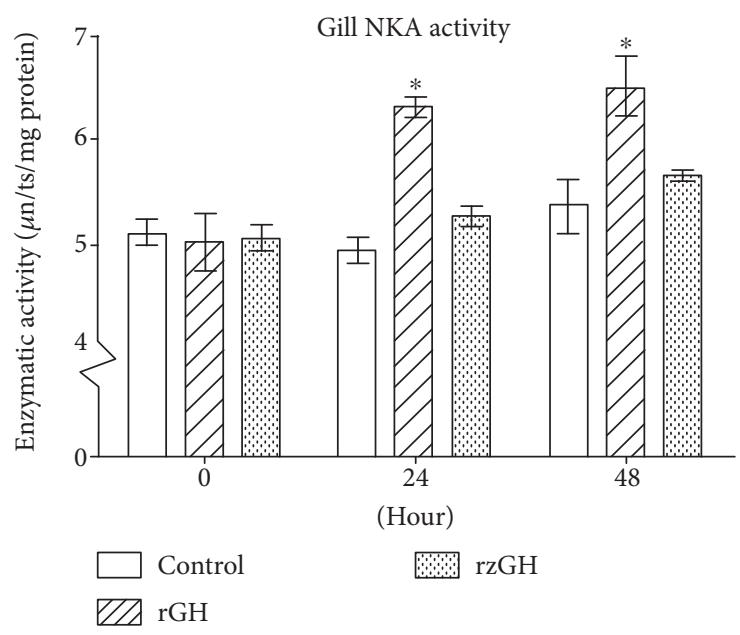

(e)

Figure 3: Induction of $n k a$ and $n k c c$ expressions by rGHl. (a) Expression of $n k a$ in the gill cultures in response to rGHl or rzGH (concentrations ranging from $10 \mathrm{ng} / \mathrm{ml}$ to $1000 \mathrm{ng} / \mathrm{ml}$ ). (b) Expression of $n k c c$ in the gill cultures in response to rGHl or rzGH (concentrations ranging from $10 \mathrm{ng} / \mathrm{ml}$ to $1000 \mathrm{ng} / \mathrm{ml}$ ). (c) Expression of $n k a$ in the gill of amphioxus injected with saline, rGHl, or rzGH. (d) Expression of $n k c c$ in the gill of amphioxus injected with saline, rGHl, or rzGH. (e) NKA activity in the gill of amphioxus injected with saline, $\mathrm{rGHl}$, or rzGH. One unit of enzymatic activity was defined as $1 \mu$ moles ADP released per hour. Data were from 3 independent experiments and expressed as mean \pm SEM. The symbol $*$ shows $p<0.05$. 


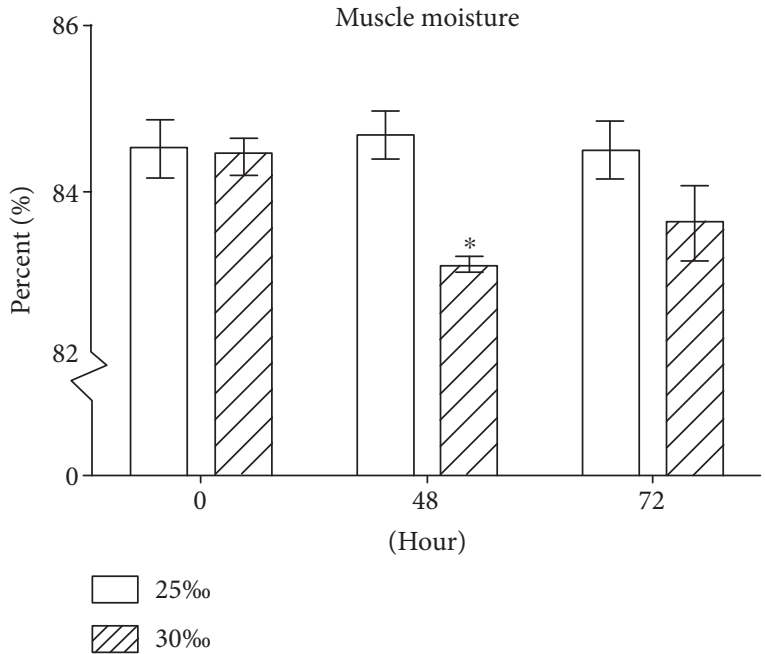

(a)

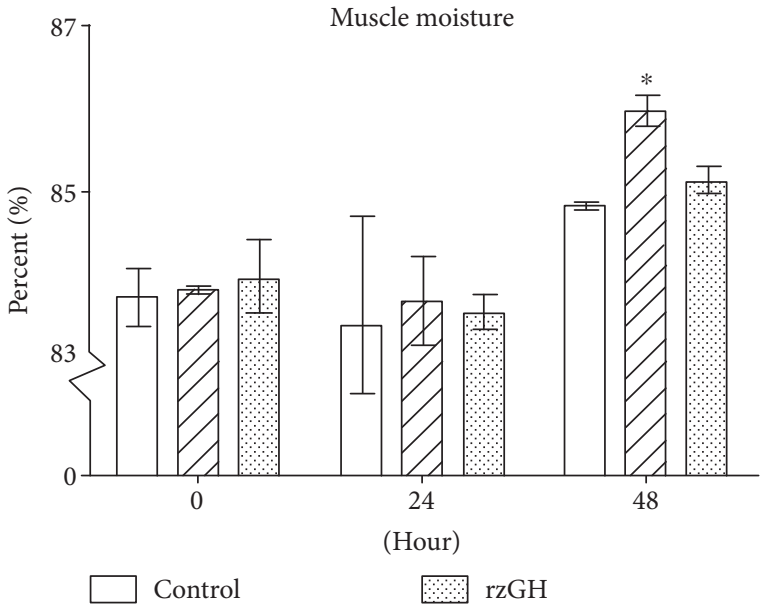

(b)

FIgURe 4: Muscle moisture of amphioxus. (a) Muscle moisture of amphioxus cultured under 25\%o or 30\%o salinity. (b) Muscle moisture of amphioxus injected with saline, $\mathrm{rGHl}$, or $\mathrm{rzGH}$. The animals were cultured in natural seawater. Data were from 3 independent experiments and expressed as mean \pm SEM. The symbol $*$ shows $p<0.05$.

salinity resulted in a significant upregulation of $n k a$ and $n k c c$ in the gill. Compared with that of $25 \%$ group, the expression of $n k a$ in the gill of $30 \%$ group was increased to approximately 1.9 -fold at 48 and $72 \mathrm{~h}$ after transfer. Similarly, compared with that of $25 \%$ group, the expression of $n k c c$ in the gill of $30 \%$ group was increased to about 1.8 -fold and 5.7 -fold, respectively, at 48 and at $72 \mathrm{~h}$ after transfer. These suggested that NKA and NKCC were involved in the process of osmoregulation in the gill of amphioxus.

Next, we tested if rGHl can stimulate the expression of $n k a$ and $n k c c$ in amphioxus gill. qRT-PCR showed that both $\mathrm{rGHl}$ and $\mathrm{rzGH}$ were capable of inducing an upregulation of $n k a$ and $n k c c$ in a dose-dependent manner in the gill cultures. The expression of $n k a$ in the gill cultures was increased to about 1.8 -fold after treatment with $1000 \mathrm{ng} / \mathrm{ml} \mathrm{rGHl}$ (compared with control; the same below); similarly, the expression of the same gene in the gill cultures increased to about 1.4 -fold after treatment with $1000 \mathrm{ng} / \mathrm{ml} \mathrm{rzGH}$. Moreover, the expression of $n k c c$ in the gill cultures was increased to about 3.7-fold and 2.0-fold, respectively, after treatment with 100 and $1000 \mathrm{ng} / \mathrm{ml} \mathrm{rGHl}$, and its expression in the gill cultures was increased to about 1.7 -fold and 4.4 fold, respectively, after treatment with 100 and $1000 \mathrm{ng} / \mathrm{ml}$ rzGH (Figures 3(a) and 3(b)). These indicated that GHl acted on the gill directly in a dose-dependent fashion in vitro for the first time, with $100 \mathrm{ng} / \mathrm{ml}$ concentration of rGHl being most effective in triggering the expression of $n k a$ and $n k c c$. Interestingly, incubation with $1000 \mathrm{ng} / \mathrm{ml} \mathrm{rGHl}$ resulted in lowered expression of the genes. rzGH also displayed similar trend as rGHl. The reason for this trend is not clear at present. Possibly, it may be due to the failure of GHR dimerization caused by higher dose of rGHl or rzGH [33].

Injection of $\mathrm{rGHl}$ or rzGH into amphioxus also induced an increased expression of $n k a$ and $n k c c$ in the gill in vivo. Compared with control group within the same time (the same below), the expression levels of $n k a$ in the gill were upregulated about 1.5-fold and 2.0-fold at 24 and $48 \mathrm{~h}$ after injection of $\mathrm{rGHl}$, and the expression levels of the same gene upregulated about 1.3-fold and 1.8-fold at 24 and $48 \mathrm{~h}$ after injection of rzGH. Similarly, the expression of $n k c c$ in the gill was about 1.8-fold higher than that of control at $48 \mathrm{~h}$ after injection of $\mathrm{rGHl}$, and the expression of $n k c c$ in the same tissue was about 1.9-fold higher than that of control at $48 \mathrm{~h}$ after injection of rzGH (Figures 3(c) and $3(\mathrm{~d})$ ). In addition, enzymatic activity assay revealed that injection of rGHl or rzGH into amphioxus triggered an increase in NKA activity in the gill at 24 to $48 \mathrm{~h}$, consistent with the results of nka expression. The gill NKA activity in the gill of control group was $5.098 \mathrm{U} / \mathrm{mg}, 4.951 \mathrm{U} / \mathrm{mg}$, and $5.363 \mathrm{U} / \mathrm{mg}$, respectively, at $0 \mathrm{~h}, 24 \mathrm{~h}$, and $48 \mathrm{~h}$ after injection. By contrast, the NKA activity in the gill of $\mathrm{rGHl}$ group was $5.028 \mathrm{U} / \mathrm{mg}, 6.304 \mathrm{U} / \mathrm{mg}$, and $6.486 \mathrm{U} / \mathrm{mg}$, individually, at $0 \mathrm{~h}, 24 \mathrm{~h}$, and $48 \mathrm{~h}$ after injection, and the NKA activity in the gill of rzGH group was $5.044 \mathrm{U} / \mathrm{mg}$, $5.259 \mathrm{U} / \mathrm{mg}$, and $5.638 \mathrm{U} / \mathrm{mg}$, separately, at $0 \mathrm{~h}, 24 \mathrm{~h}$, and $48 \mathrm{~h}$ after injection (Figure 3(e)). Several studies have shown that injection of vertebrate GH induced about 1.5 -fold to 2fold increase in the NKA and NKCC in fish gill $[11,16,28]$. We demonstrated that amphioxus GHl, like vertebrate $\mathrm{GH}$, was able to induce the expression of $n k a$ and $n k c c$ in the gill in vivo. Besides, the trends of changes in the NKA activity and $n k a$ expression patterns affected by rGHl were both similar to that of rzGH. These showed that amphioxus $\mathrm{GHl}$ as well as zebrafish GH had a similar capacity to stimulate the expression of $n k a$ and $n k c c$, suggesting that $\mathrm{GHl}$ was able to mediate the salinity tolerance in amphioxus.

3.3. $r$ GHl Increases Muscle Moisture. Muscle usually loses moisture under high salinity environment. Thus, the relationship between salinity change and muscle moisture was tested. When the $25 \%$ salinity-acclimated animals were transferred to seawater with $30 \%$ o salinity, their muscle 


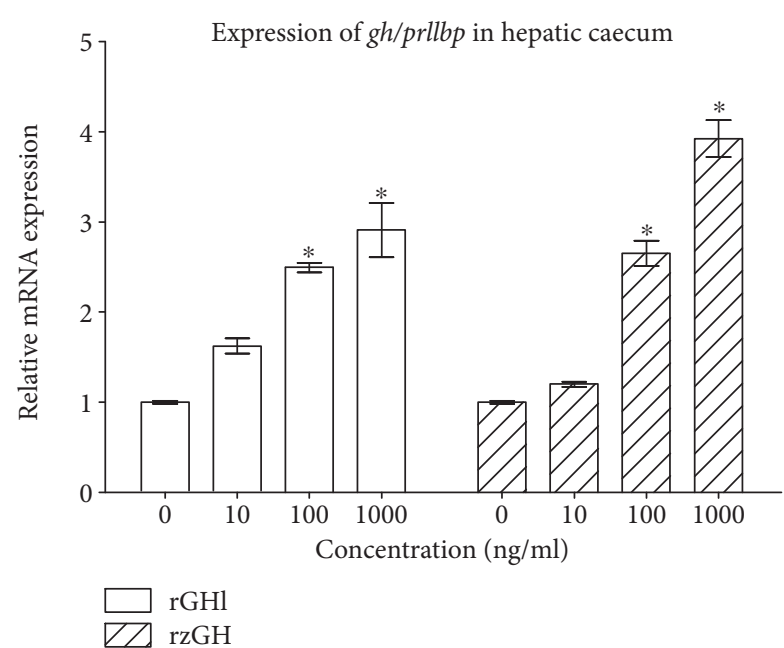

(a)

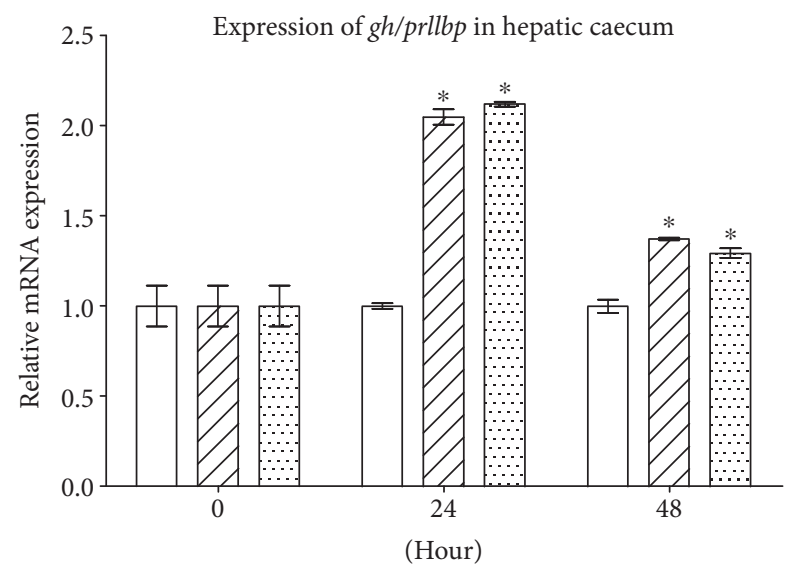

Control rGHl

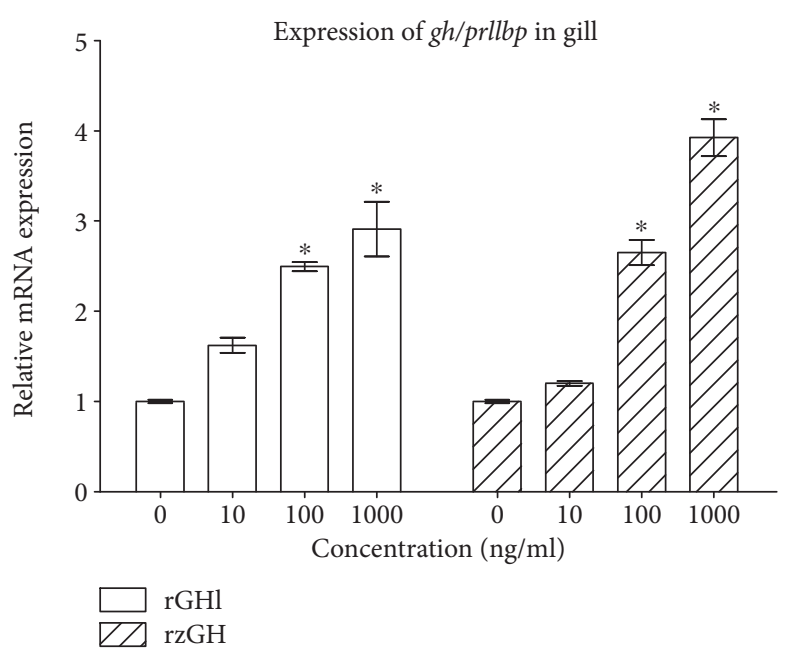

(b)
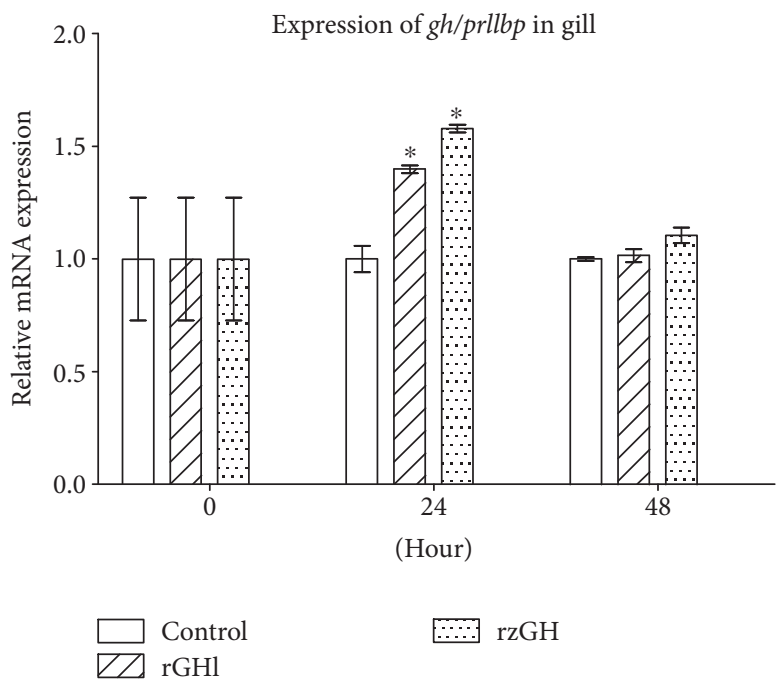

(c)

(d)

FIGURE 5: Induction of $g h / p r l l b p$ expression by rGHl. (a) Expression of $g h / p r l l b p$ in the cultures of the hepatic caecum in response to rGHl or rzGH (concentrations ranging from $10 \mathrm{ng} / \mathrm{ml}$ to $1000 \mathrm{ng} / \mathrm{ml}$ ). (b) Expression of gh/prllbp in the cultures of the gill in response to rGHl or rzGH (concentrations ranging from $10 \mathrm{ng} / \mathrm{ml}$ to $1000 \mathrm{ng} / \mathrm{ml}$ ). (c) Expression of gh/prllbp in the hepatic caecum of amphioxus injected with saline, rGHl, or rzGH. (d) Expression of gh/prllbp in the gill of amphioxus injected with saline, rGHl, or rzGH. Data were from 3 independent experiments and expressed as mean \pm SEM. The symbol $*$ shows $p<0.05$.

moisture was $83.1 \%$ and $83.6 \%$ at 48 and $72 \mathrm{~h}$ after the transfer (Figure 4(a)), respectively. It is clear that the muscle moisture of the animals transferred to $30 \%$ salinity was significantly lower than that of $25 \%$ o salinity-acclimated animals at $48 \mathrm{~h}$ after transfer. This indicated that higher salinity could reduce the muscle moisture of amphioxus in a short term.

Next, we tested the effect of rGHl on muscle moisture. When the animals cultured under 30\%o salinity were injected with saline, their muscle moisture was $83.4 \%$ and $84.8 \%$ at 24 and $48 \mathrm{~h}$ after injection (Figure 4(b)), respectively. By contrast, when the same animals were injected with saline plus $\mathrm{rGHl}$ or $\mathrm{rzGH}$, their muscle moisture was increased to $83.7 \%$ and $86.0 \%$ as well as $83.5 \%$ and $85.1 \%$ at 24 and $48 \mathrm{~h}$ after injection (Figure 4(b)), individually. These indicated that $\mathrm{rGHl}$ as well as rzGH could increase the muscle moisture of amphioxus, providing an additional evidence that $\mathrm{GHl}$ was a regulator of salinity tolerance.

3.4. rGHl Induces Expression of gh/prllbp. Sohm et al. [34] and Einarsdóttir et al. [35] both showed that GHBP was upregulated by GH and higher salinity in fish. To test if the GH/PRLIBP is associated with salinity tolerance of amphioxus, we examined the effects of rGHl and rzGH on the expression of gh/prllbp in the hepatic caecum and gill. As shown in Figures 5(a) and 5(b), both rGHl and rzGH clearly induced the expression of $g h / p r l l b p$ in the tissue cultures of gill and hepatic caecum in a dose-dependent fashion (compared with control) which was similar to the results obtained by Sohm et al. [34] and Einarsdóttir et al. [35]. Similarly, injection of rGHl and rzGH stimulated the expression of gh/prllbp in the gill and hepatic caecum; and 


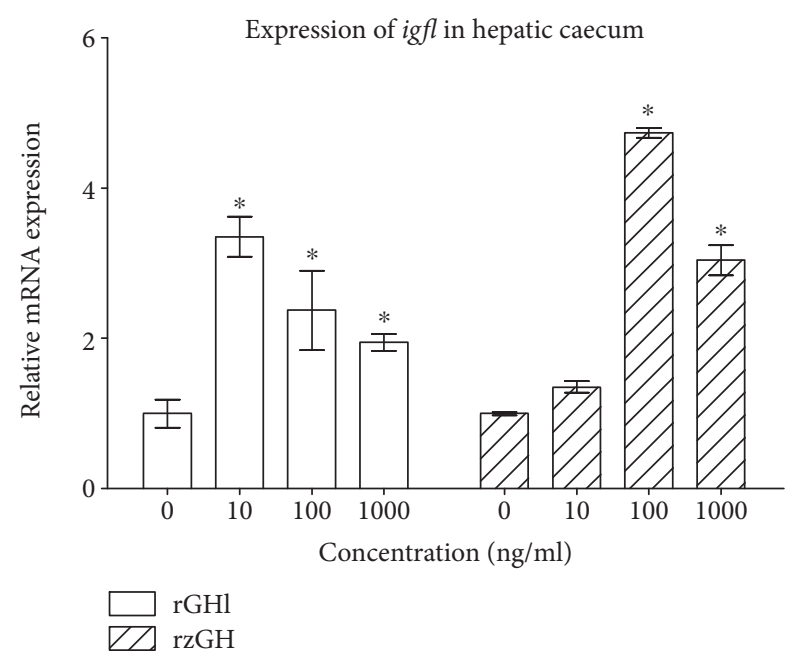

(a)

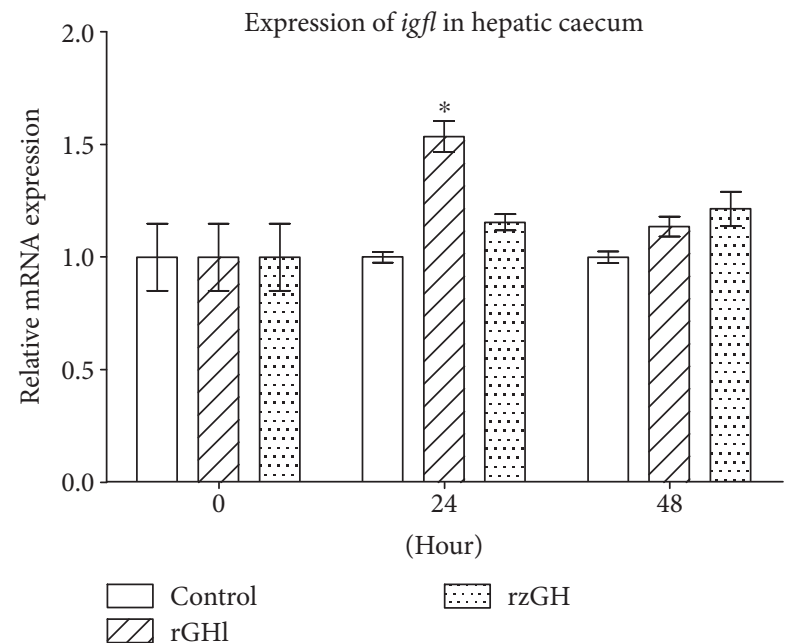

(c)

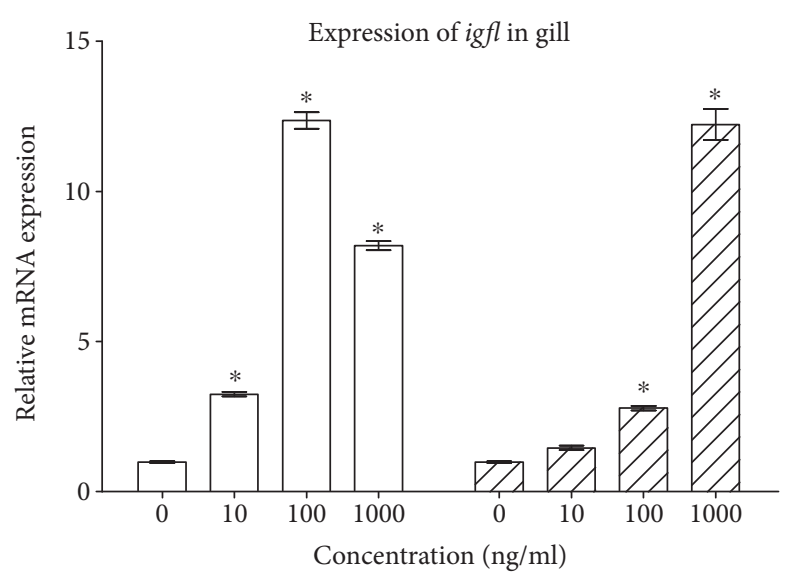

(b)

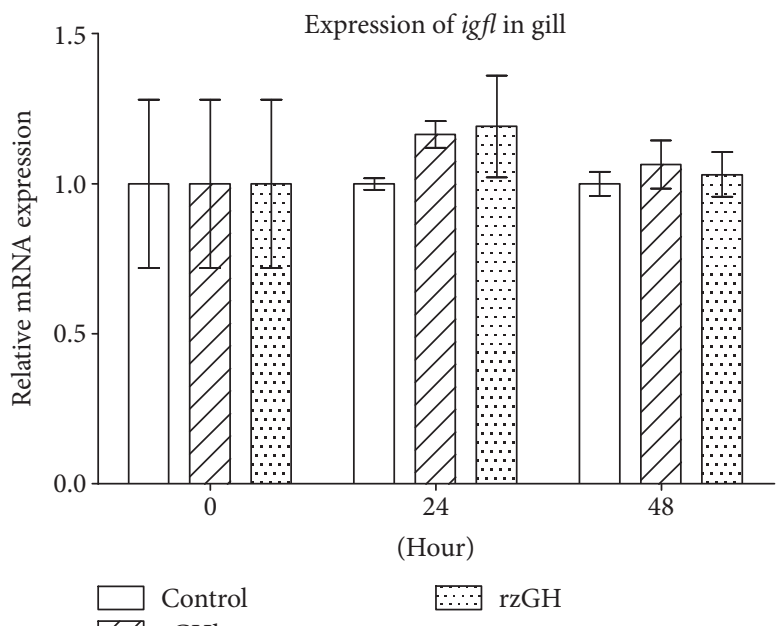

(d)

Figure 6: Induction of igfl expression by rGHl. (a) Expression of igfl in the cultures of the hepatic caecum in response to rGHl or rzGH (concentrations ranging from $10 \mathrm{ng} / \mathrm{ml}$ to $1000 \mathrm{ng} / \mathrm{ml}$ ). (b) Expression of igfl in the cultures of the gill in response to rGHl or rzGH (concentrations ranging from $10 \mathrm{ng} / \mathrm{ml}$ to $1000 \mathrm{ng} / \mathrm{ml}$ ). (c) Expression of gh/prllbp in the hepatic caecum of amphioxus injected with saline, rGHl, or rzGH. (d) Expression of igfl in the gill of amphioxus injected with saline, rGHl, or rzGH. Data were from 3 independent experiments and expressed as mean \pm SEM. The symbol $*$ shows $p<0.05$.

this increase in gh/prlllbp expression (Figures 5(c) and 5(d); compared with the control within the same time) was always related to higher concentration of rGHl or rzGH. These suggested that amphioxus $\mathrm{GHl}$ as well as zebrafish GH both could upregulate the expression of gh/prllbp in the gill and hepatic caecum, thereby contributing to salinity tolerance.

3.5. $r$ GHl Induces Expression of igfl. GHl was shown to be able to regulate growth through IGF action; thus, we tested the effects of rGHl and rzGH on the expression of igfl in the hepatic caecum and gill of amphioxus. As shown in Figures 6(a) and 6(b), both $\mathrm{rGHl}$ and $\mathrm{rzGH}$ induced the expression of igfl in the tissue cultures of hepatic caecum and gill in a dose-dependent fashion (compared with control). Moreover, injection of rGHl and rzGH stimulated the expression of igfl in the hepatic caecum (Figure 6(c); compared with control within the same time; the same below), though it had little effect on the expression of igfl in the gill (Figure 6(d)). The reason for this is not clear at present, but one possibility is that rGHl level transported to the gill by circulation might be rather lower because most $\mathrm{rGHl}$ had bound to its receptor in the hepatic caecum. Together, these data showed that amphioxus GHl could mediate salinity tolerance via stimulating the expression of igfl.

3.6. Salinity Increase Induces Expression of ghl, gh/prllbp, and igfl. To test if a vertebrate-like GH-IGF axis is involved in the osmoregulation in amphioxus, we transferred the $25 \%$ salinity-acclimated animals to seawater with $30 \%$ salinity and examined the effects of salinity change on the expression of $g h l$ in the Hatschek's pit and gill as well as gh/prllbp and igfl in the hepatic caecum and gill. No dead animals were 


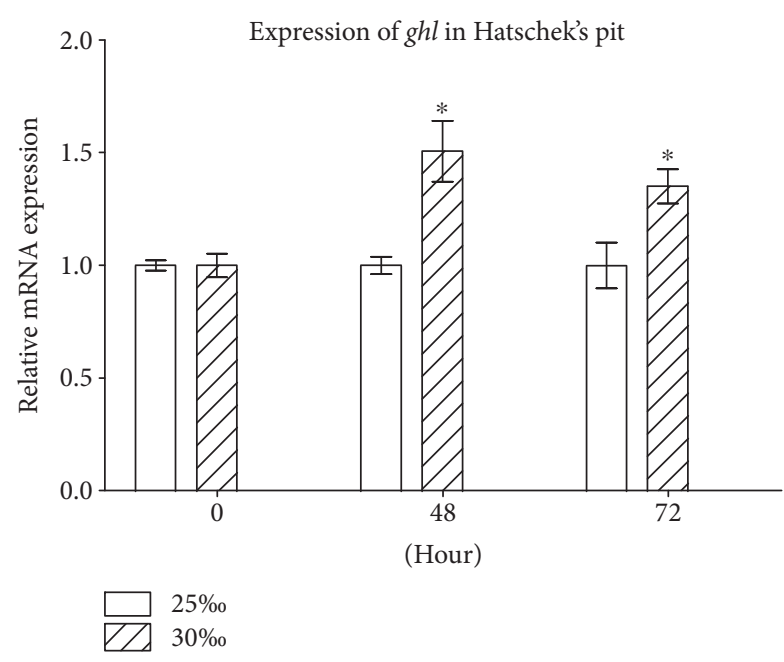

(a)

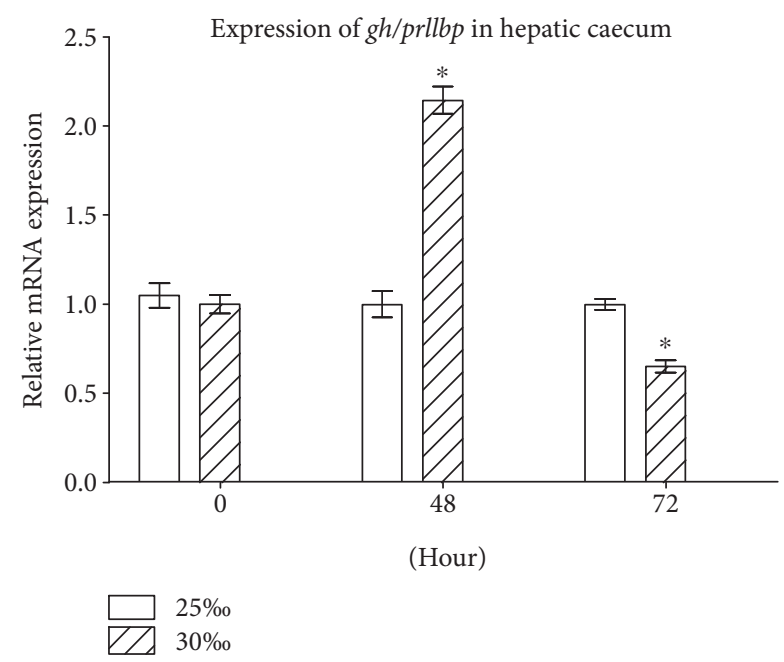

(c)

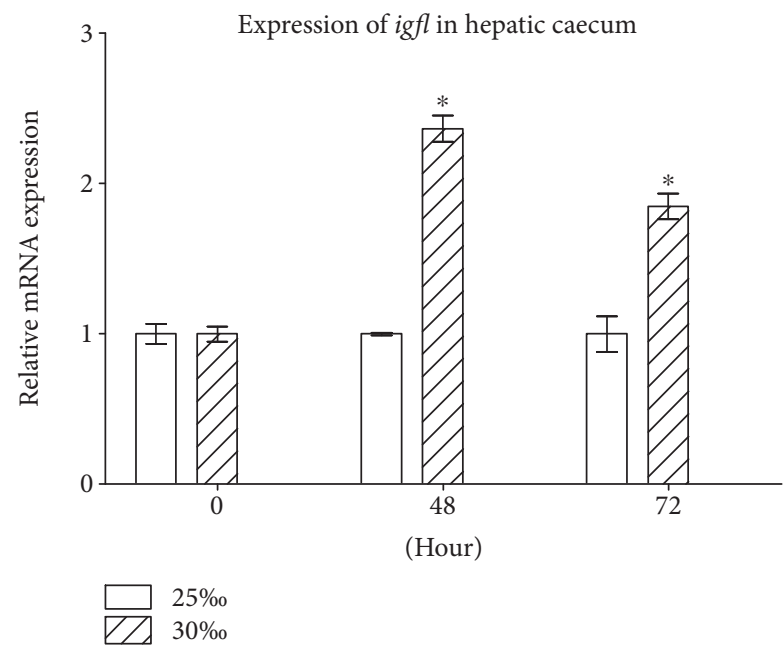

(e)

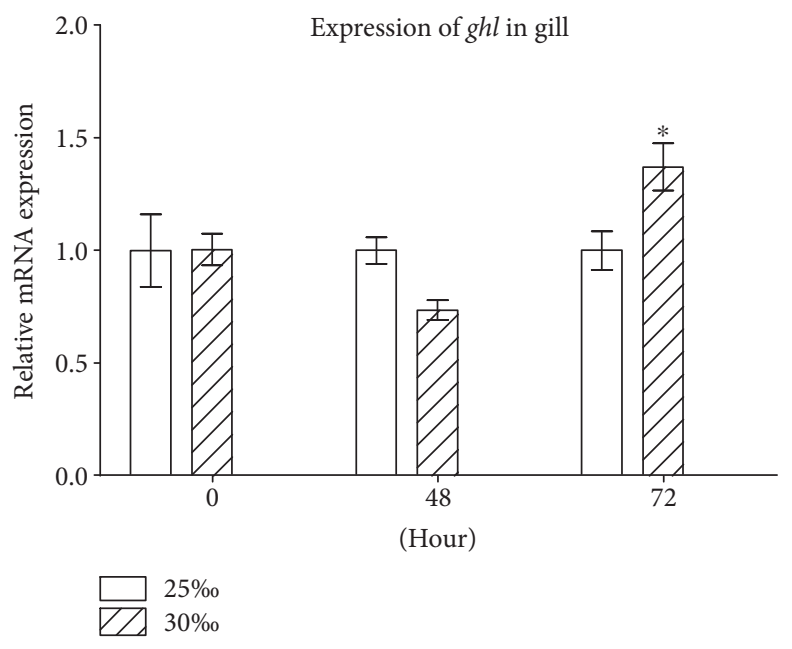

(b)

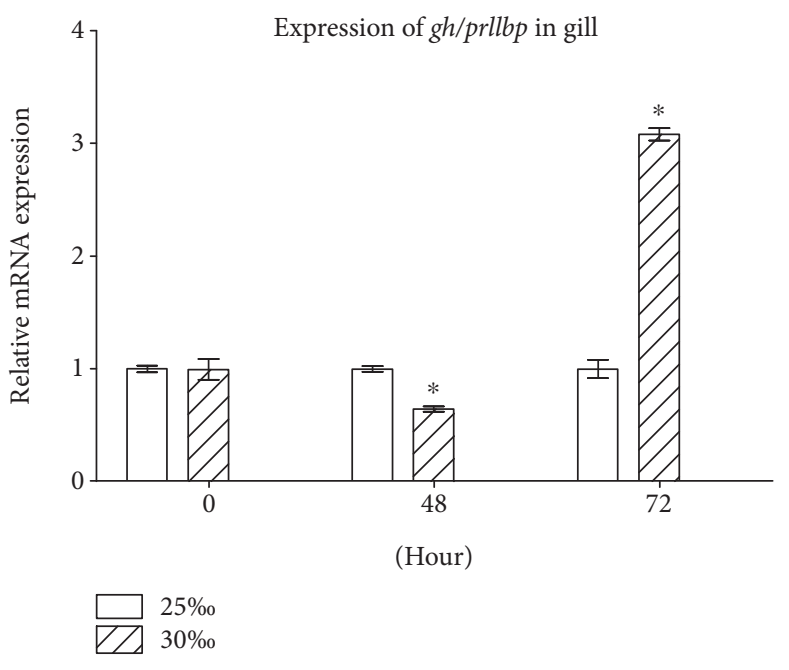

(d)

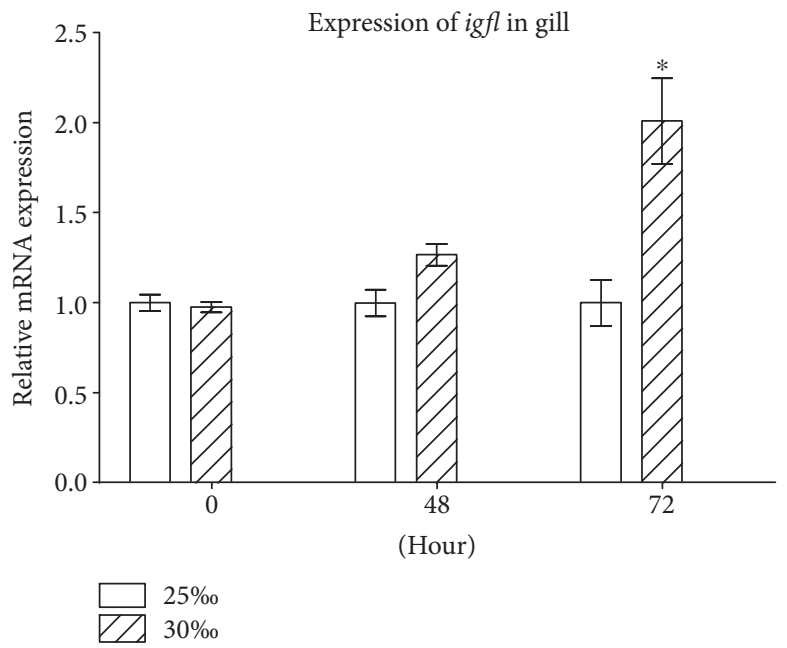

(f)

Figure 7: Expression of ghl/igfl axis genes of amphioxus cultured under 25\%o or 30\%o salinity. (a) Expression of ghl in the Hatschek's pit. (b) Expression of $g h l$ in the gill. (c) Expression of gh/prllbp in the hepatic caecum. (d) Expression of gh/prllbp in the gill. (e) Expression of $i g f l$ in the hepatic caecum. (f) Expression of igfl in the gill. Data were from 3 independent experiments and expressed as mean \pm SEM. The symbol $*$ shows $p<0.05$. 


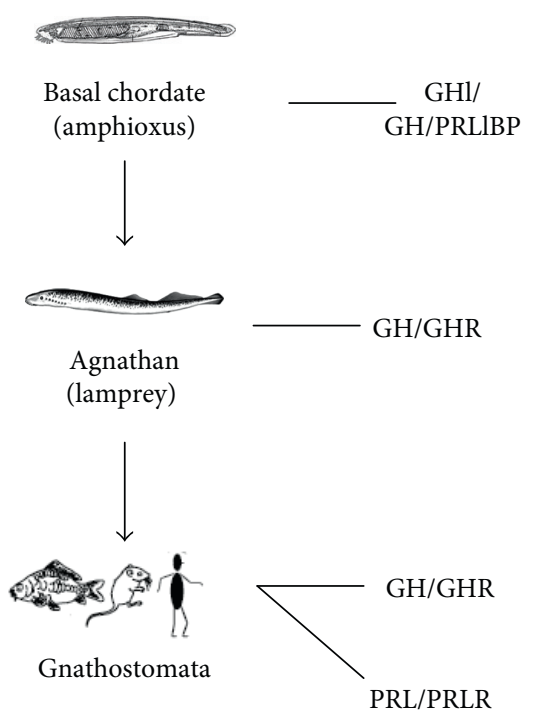

(a)

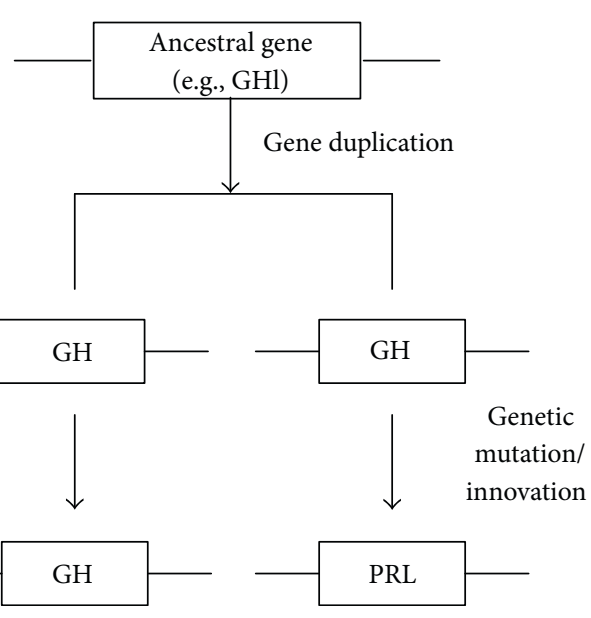

(b)

FIGURE 8: A proposed model for the evolution of GH/PRL family. (a) Ancestral GH/GHR system already emerged in the basal chordate, and PRL/PRLR originated with the advent of Gnathostomata. (b) The ancestral gene, like amphioxus GHl gene, generated two genes by gene duplication early in vertebrate evolution. One of the resulting genes evolved directly into GH gene in modern Gnathostomata, while the other gene evolved into PRL gene, possibly due to adaptation of FW habitats, by genetic innovations and/or mutation after split of agnathan/Gnathostomata.

observed during the experimental periods. The transfer of $25 \%$ salinity-acclimated amphioxus to seawater with $30 \%$ salinity resulted in upregulation of $g h l$ in the Hatschek's pit (Figure 7(a); compared with control within the same time; the same below) and gill (Figure 7(b)) as well as igfl in the hepatic caecum (Figure 7(e)) and gill (Figure 7(f)). The expression level of gh/prllbp in the hepatic caecum at $48 \mathrm{~h}$ after transfer (Figure $7(\mathrm{c})$ ) well matched that of gh expression (Figure 7(a)). However, gh/prllbp expression in the tissue was soon decreased at $72 \mathrm{~h}$ after transfer (Figure 7(c)), suggesting that GH/PRLlBP may be also subjected to the downregulation by other factors independent of GHl [35]. Notably, as shown in Figure 7(a), ghl expression was upregulated at $48 \mathrm{~h}$ after transfer, but the expression of igfl in the gill at $48 \mathrm{~h}$ after transfer was not significantly elevated (Figure $7(\mathrm{f})$ ). These indicated that the hepatic caecum was the primary target tissue of GHl. It should be noticed that even though there was little GHl binding in the gill, $n k a$ and $n k c c$ in the gill were still significantly upregulated (Figures 2(c) and 2(d)). These suggested that IGFl, the mediator of $\mathrm{GHl}$ secreted by the hepatic caecum, may play a critical role in osmoregulation as IGF-I in fish [20,21]. Together, all the data suggested that a vertebrate-like GHl/IGF system may be involved in osmoregulation in amphioxus.

\section{Discussion}

Functions of GH are diverse, with its growth-promoting and osmoregulatory activities being studied most extensively and intensively $[4,5,7,36]$. Amphioxus GH-like protein GHl has been shown to have growth-promoting activity. Here, we demonstrate clearly that $\mathrm{GHl}$ has the capacity to mediate osmoregulation, as evidenced by the observations that $\mathrm{GHl}$ enhances not only survival rate of amphioxus but also muscle moisture under high salinity. In addition, we show that GHl induces upregulation of both the ion transporter NKA and cotransporter NKCC in the gill as well as mediator of GH action IGFl in the hepatic caecum, indicating that GHI apparently fulfills this osmoregulatory activity through the same mechanisms of vertebrate GH. Collectively, these data suggest that osmoregulatory activities of GH already emerged in the basal chordate [37], much earlier than thought before [38].

Teleosts are well adapted for ion exchange using active and passive mechanisms across various surface membranes to keep the osmotic pressure of their body fluids steady when they face relatively hyperosmotic or hypoosmotic environment [39]. Interestingly, Huang [40] has reported that the average osmotic pressure of amphioxus body fluids was about $780 \mathrm{mOsm} / \mathrm{L}$, which was significantly lower than that of ambient seawater, $1200 \mathrm{mOsm} / \mathrm{L}$, suggesting that amphioxus may be able to transport ions across surface membranes to achieve proper osmotic balance and hydration status. However, this demands further study.

The gill, in addition to being a respiratory organ, is the primary site of net sodium and chloride transport in fishes, and the roles of chloride cells in the gill are well accepted as the principal site of ion extrusion in seawater or in a hypertonic environment $[18,41]$. The ciliated gill bars of amphioxus are radically different from fish gill structure, and if they function in respiration remains controversial [42-44]. We show that $\mathrm{GHl}$ is able to induce the expression of both $n k a$ and $n k c c$ as well as gh/prllbp in the gill of amphioxus, suggesting that the gill may also be the main osmoregulatory organ in amphioxus. 
GHl has been shown to be the only member of the vertebrate pituitary hormone family in amphioxus, which is capable of promoting growth [26]. Here, we show that GHl is involved in the mediation of osmoregulation. It is apparent that $\mathrm{GHl}$ plays a dual role of both growth promotion and osmoregulation. These allow us to propose that the function of the ancestral gene that contributed to the origin of GH/PRL family was to regulate not only somatic growth (i.e., GH-like) but also hydrominal balance (i.e., PRL-like). Thus, the ancestral gene, like amphioxus $g h l$, might generate two genes by gene duplication early in vertebrate evolution. One of the resulting genes evolved directly into $\mathrm{GH}$ gene in modern gnathans, while the other gene evolved into PRL gene, possibly due to adaptation of FW habitats, by genetic innovations and/or mutation after split of agnathans/gnathans (Figure 8). Previously, two models have been suggested to depict the origin of GH/PRL family. The first model was developed on the basis of the examination of vertebrate history and the study of ancient chordates and suggests that the primary function of the ancestral gene that gave rise to the GH/PRL family was GH-like; that is, its original activity was to regulate somatic growth, while PRL activity evolved later, perhaps to allow for the colonization of FW habitats. The opposing view claims that the ancestral gene was involved in osmoregulation, because this one function is common to fish PRL and GH [45]. It is obvious that the two old models become unified in our new model. Of note, only GH but not PRL have been detected in lamprey $[46,47]$. Thus, the growth-promoting and osmoregulatory properties of the single hormone remained unchanged in agnathans. Further comparative and functional studies of $\mathrm{GH}$ and PRL will shed more light on the divergence and development of these structurally and functionally related hormones and their receptors.

In conclusion, this study highlights amphioxus $\mathrm{GHl}$, in addition to growth-promoting activity, which can mediate osmoregulation through the same mechanisms of vertebrate $\mathrm{GH}$. It also proposes a new model depicting the origin of $\mathrm{GH} / \mathrm{PRL}$ family in vertebrates.

\section{Conflicts of Interest}

The authors declare that there is no interest that could be perceived as prejudicing the impartiality of the research reported.

\section{Acknowledgments}

This work was supported by the grants of the Natural Science Foundation of China (31172071) and the China Postdoctoral Science Foundation (2014M561964).

\section{References}

[1] J. Boulay, J. O'Shea, and W. Paul, "Molecular phylogeny within type I cytokines and their cognate receptors," Immunity, vol. 19, no. 2, pp. 159-163, 2003.

[2] M. Huising, C. Kruiswijk, and G. Flik, "Phylogeny and evolution of class-I helical cytokines," Journal of Endocrinology, vol. 189, no. 1, pp. 1-25, 2006.
[3] M. Ono, Y. Takayama, M. Rand-Weaver et al., "cDNA cloning of somatolactin, a pituitary protein related to growth hormone and prolactin," Proceedings of the National Academy of Sciences, vol. 87, no. 11, pp. 4330-4334, 1990.

[4] I. Forsyth and M. Wallis, "Growth hormone and prolactinmolecular and functional evolution," Journal of Mammary Gland Biology and Neoplasia, vol. 7, no. 3, pp. 291-312, 2002.

[5] N. D. Horseman and L. Y. Yu-Lee, "Transcriptional regulation by the helix bundle peptide hormones: growth hormone, prolactin, and hematopoietic cytokines," Endocrine Reviews, vol. 15, no. 5, pp. 627-649, 1994.

[6] S. D. McCormick, "Endocrine control of osmoregulation in teleost," Washington American Zoologist, vol. 41, no. 4, pp. 781-794, 2001.

[7] T. Sakamoto and S. D. McCormick, "Prolactin and growth hormone in fish osmoregulation," General and Comparative Endocrinology, vol. 147, no. 1, pp. 24-30, 2006.

[8] T. Sakamoto, S. D. Mccormick, and T. Hirano, "Osmoregulatory actions of growth hormone and its mode of action in salmonids: a review," Fish Physiology and Biochemistry, vol. 11, no. 1-6, pp. 155-164, 1993.

[9] B. Auperin, I. Leguen, F. Rentier-Delrue, J. Smal, and P. Prunet, "Absence of a tiGH effect on adaptability to brackish water in tilapia (Oreochromis niloticus)," General and Comparative Endocrinology, vol. 97, no. 1, pp. 145-159, 1995.

[10] B. Xu, H. Miao, P. Zhang, and D. Li, “Osmoregulatory actions of growth hormone in juvenile tilapia (Oreochromis niloticus)," Fish Physiology and Biochemistry, vol. 17, no. 1-6, pp. 295-301, 1997.

[11] J. M. Mancera and S. D. McCormick, "Evidence for growth hormone/insulin-like growth factor I axis regulation of seawater acclimation in the euryhaline teleost Fundulus heteroclitus," General and Comparative Endocrinology, vol. 111, no. 2, pp. 103-112, 1998.

[12] G. E. Pickford and J. G. Phillips, "Prolactin, a factor in promoting survival of hypophysectomized killifish in fresh water," Science, vol. 130, no. 3373, pp. 454-455, 1959.

[13] M. Dharmamba and J. Maetz, "Effects of hypophysectomy and prolactin on the sodium balance of Tilapia mossambica in fresh water," General and Comparative Endocrinology, vol. 19, no. 1, pp. 175-183, 1972.

[14] S. S. Madsen, M. K. Jensen, J. Nohr, and K. Kristiansen, "Expression of $\mathrm{Na}^{+}-\mathrm{K}^{+}$-ATPase in the brown trout, Salmo trutta: in vivo modulation by hormones and seawater," American Journal of Physiology-Regulatory, Integrative and Comparative Physiology, vol. 269, no. 6, pp. R1339-R1345, 1995.

[15] T. Sakamoto, B. S. Shepherd, S. S. Madsen et al., "Osmoregulatory actions of growth hormone and prolactin in an advanced teleost," General and Comparative Endocrinology, vol. 106, no. 1, pp. 95-101, 1997.

[16] R. Pelis and S. D. McCormick, "Effects of growth hormone and cortisol on $\mathrm{Na}^{+}-\mathrm{K}^{+}-2 \mathrm{Cl}^{-}$co-transporter localization and abundance in the gills of Atlantic salmon," General and Comparative Endocrinology, vol. 124, no. 2, pp. 134-143, 2001.

[17] P. Silva, R. Solomon, K. Spokes, and F. Epstein, "Ouabain inhibition of gill $\mathrm{Na}^{+}-\mathrm{K}^{+}$-ATPase: relationship to active chloride transport," Journal of Experimental Zoology, vol. 199, no. 3, pp. 419-426, 1977.

[18] K. J. Degnan, "Chloride secretion by teleost gill and operculum," in Chloride Transport Coupling in Biological Membranes and Epithelia, Elsevier, Amsterdam, Netherlands, 1984. 
[19] C. H. Tang and T. H. Lee, "The effect of environmental salinity on the protein expression of $\mathrm{Na}^{+} / \mathrm{K}^{+}$-ATPase, $\mathrm{Na}^{+} / \mathrm{K}^{+} / 2 \mathrm{Cl}^{-}$ cotransporter, cystic fibrosis transmembrane conductance regulator, anion exchanger 1, and chloride channel 3 in gills of a euryhaline teleost, Tetraodon nigroviridis," Comparative Biochemistry and Physiology. Part A, Molecular \& Integrative Physiology, vol. 147, no. 2, pp. 521-528, 2007.

[20] S. S. Madsen and H. A. Bern, "In-vitro effects of insulin-like growth factor-I on gill $\mathrm{Na}^{+}, \mathrm{K}^{+}$-ATPase in coho salmon, Oncorhynchus kisutch," Journal of Endocrinology, vol. 138, no. 1, pp. 23-30, 1993.

[21] C. Duan, "The insulin-like growth factor system and its biological actions in fish," American Zoologist, vol. 37, no. 6, pp. 491-503, 1997.

[22] T. Hirano, "The spectrum of prolactin action in teleosts," Progress in Clinical and Biological Research, vol. 205, pp. 53-74, 1986.

[23] L. A. Manzon, "The role of prolactin in fish osmoregulation: a review," General and Comparative Endocrinology, vol. 125, no. 2, pp. 291-310, 2002.

[24] J. P. Breves, S. D. Mccormick, and R. O. Karlstrom, "Prolactin and teleost ionocytes: new insights into cellular and molecular targets of prolactin in vertebrate epithelia," General and Comparative Endocrinology, vol. 203, pp. 21-28, 2014.

[25] Y. Takei, J. Hiroi, H. Takahashi, and T. Sakamoto, "Diverse mechanisms for body fluid regulation in teleost fishes," American Journal of Physiology-Regulatory, Integrative and Comparative Physiology, vol. 307, no. 7, pp. R778-R792, 2014.

[26] M. Li, Z. Gao, D. Ji, and S. Zhang, "Functional characterization of GH-like homolog in amphioxus reveals an ancient origin of GH/GH receptor system," Endocrinology, vol. 155, no. 12, pp. 4818-4830, 2014.

[27] Y. Wang and S. Zhang, "Expression and regulation by thyroid hormone $(\mathrm{TH})$ of zebrafish IGF-I gene and amphioxus IGFl gene with implication of the origin of TH/IGF signaling pathway," Comparative Biochemistry and Physiology. Part A, Molecular \& Integrative Physiology, vol. 160, no. 4, pp. 474-479, 2011.

[28] S. D. Mccormick, "Effects of growth hormone and insulin-like growth factor I on salinity tolerance and gill $\mathrm{Na}^{+}, \mathrm{K}^{+}$-ATPase in Atlantic salmon (Salmo salar): interaction with cortisol," General and Comparative Endocrinology, vol. 101, no. 1, pp. 3-11, 1996.

[29] S. Lalitha, "Primer premier 5," Biotech Software \& Internet Report: The Computer Software Journal for Scient, vol. 1, no. 6, pp. 270-272, 2000.

[30] Y. Q. Fang and L. Wang, "The preliminary study of homogenate of the wheel organ and Hatschek's pit of amphioxus on testicular development in young toad (Bufo malanostictus)," Acta Biologiae Experimentalis Sinica, vol. 1, p. 012, 1984.

[31] J. P. Breves, S. B. Serizier, V. Goffin, S. D. McCormick, and R. O. Karistrom, "Prolactin regulates transcription of the ion uptake $\mathrm{Na}^{+} / \mathrm{Cl}^{-}$cotransporter (ncc) gene in zebrafish gill," Molecular and Cellular Endocrinology, vol. 369, no. 1, pp. 98-106, 2013.

[32] L. Zeng, J. L. Lei, B. Liu, W. S. Hong, C. X. Ai, and C. R. Gao, "Effects of salinity on $\mathrm{Na}^{+}-\mathrm{K}^{+}$-ATPase activity in gills, and concentrations of ions and hormones in serum of juvenile turbot (Scophthalmus maximus)," Chinese Journal of Zoology, vol. 49, no. 3, pp. 407-414, 2014.
[33] S. J. Frank and J. L. Messina, Growth hormone receptor, cytokine reference online, 121 pages, Academic Press, Harcourt, London, 2002.

[34] F. Sohm, I. Manfroid, A. Pezet et al., "Identification and modulation of a growth hormone-binding protein in rainbow trout (Oncorhynchus mykiss) plasma during seawater adaptation," General and Comparative Endocrinology, vol. 111, no. 2, pp. 216-224, 1998.

[35] I. E. Einarsdóttir, N. Gong, E. Jönsson et al., "Plasma growth hormone-binding protein levels in Atlantic salmon Salmo salar during smoltification and seawater transfer," Journal of Fish Biology, vol. 85, no. 4, pp. 1279-1296, 2014.

[36] H. A. Bern, "Functional evolution of prolactin and growth hormone in lower vertebrates," American Zoologist, vol. 23, no. 3, pp. 663-671, 1983.

[37] N. Putnam, T. Butts, D. E. Ferrier et al., "The amphioxus genome and the evolution of the chordate karyotype," Nature, vol. 453, no. 7198, pp. 1064-1071, 2008.

[38] J. L. Specker, P. M. Ingleton, and H. A. Bern, Comparative physiology of the prolactin cell. Prolactin secretion: a multidisciplinary approach, pp. 17-30, Academic Press, 1984.

[39] M. G. Greenwell, J. Sherrill, and L.A. Clayton, "Osmoregulation in fish," The Veterinary Clinics of North America Exotic Animal Practice, vol. 6, no. 6, pp. 169-189, 2003.

[40] S. F. Huang, Comparative-genomic analysis of the amphioxus immune system and functional study of its TLR and TNF signal pathways, Doctoral dissertation, Sun Yat-sen University, 2007.

[41] M. Pisam, "Membranous systems in the "chloride cell" of teleostean fish gill; their modifications in response to the salinity of the environment," Anatomical Record, vol. 200, no. 4, pp. 401-414, 1981.

[42] G. C. Kent and L. Miller, Comparative Anatomy of Vertebrates, Wm. C. Brown Publishers, Dubuque, 1997.

[43] V. Storch and U. Welsch, Kükenthal- Zoologisches Praktikum, Spektrum Akademischer Verlag, Heidelberg, Berlin, 1999.

[44] A. Schmitz, M. Gemmel, and S. F. Perry, "Morphometric partitioning of respiratory surfaces in amphioxus (Branchiostoma lanceolatum Pallas)," Journal of Experimental Biology, vol. 203, no. 22, pp. 3381-3390, 2000.

[45] T. T. Chen, "Structure and evolution of fish growth hormone and insulin like growth factor genes," Fish Physiology, vol. 13, no. 08, pp. 179-209, 1994.

[46] H. Kawauchi, K. Suzuki, T. Yamazaki et al., "Identification of growth hormone in the sea lamprey, an extant representative of a group of the most ancient vertebrates," Endocrinology, vol. 143, no. 12, pp. 4916-4921, 2002.

[47] E. R. Ellens, J. D. Kittilson, J. A. Hall, S. A. Sower, and M. A. Sheridan, "Evolutionary origin and divergence of the growth hormone receptor family: insight from studies on sea lamprey," General and Comparative Endocrinology, vol. 192, no. 9, pp. 222-236, 2013. 


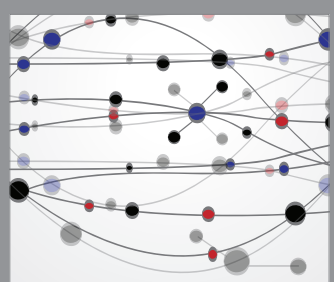

The Scientific World Journal
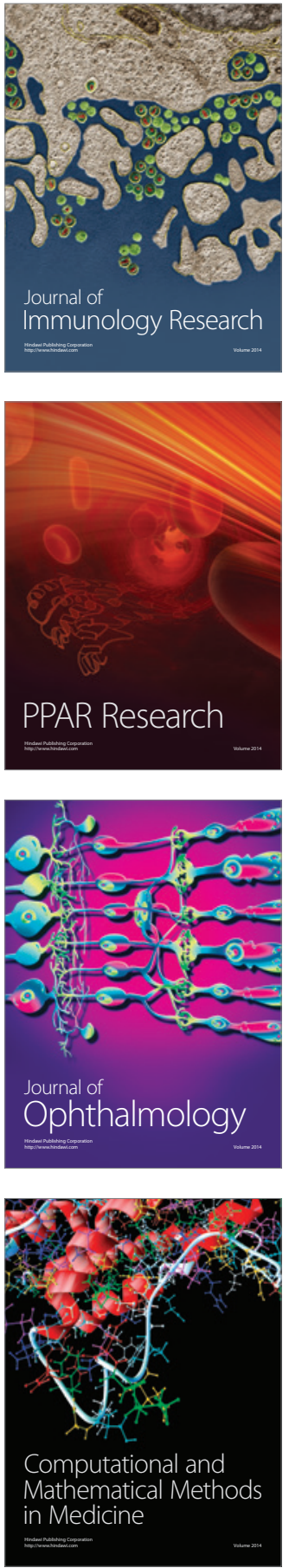

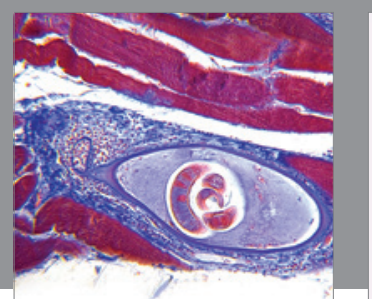

Gastroenterology Research and Practice
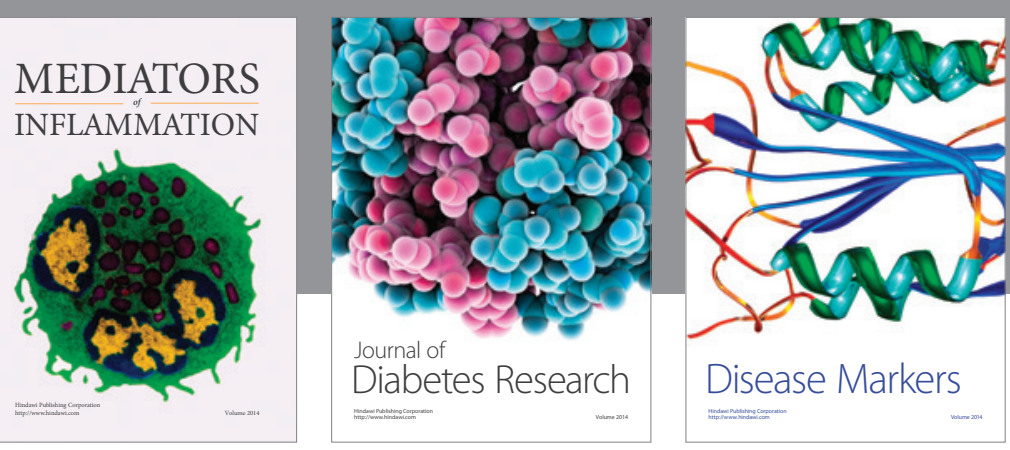

Disease Markers

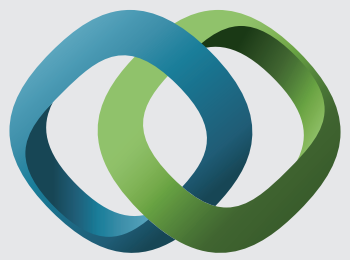

\section{Hindawi}

Submit your manuscripts at

https://www.hindawi.com
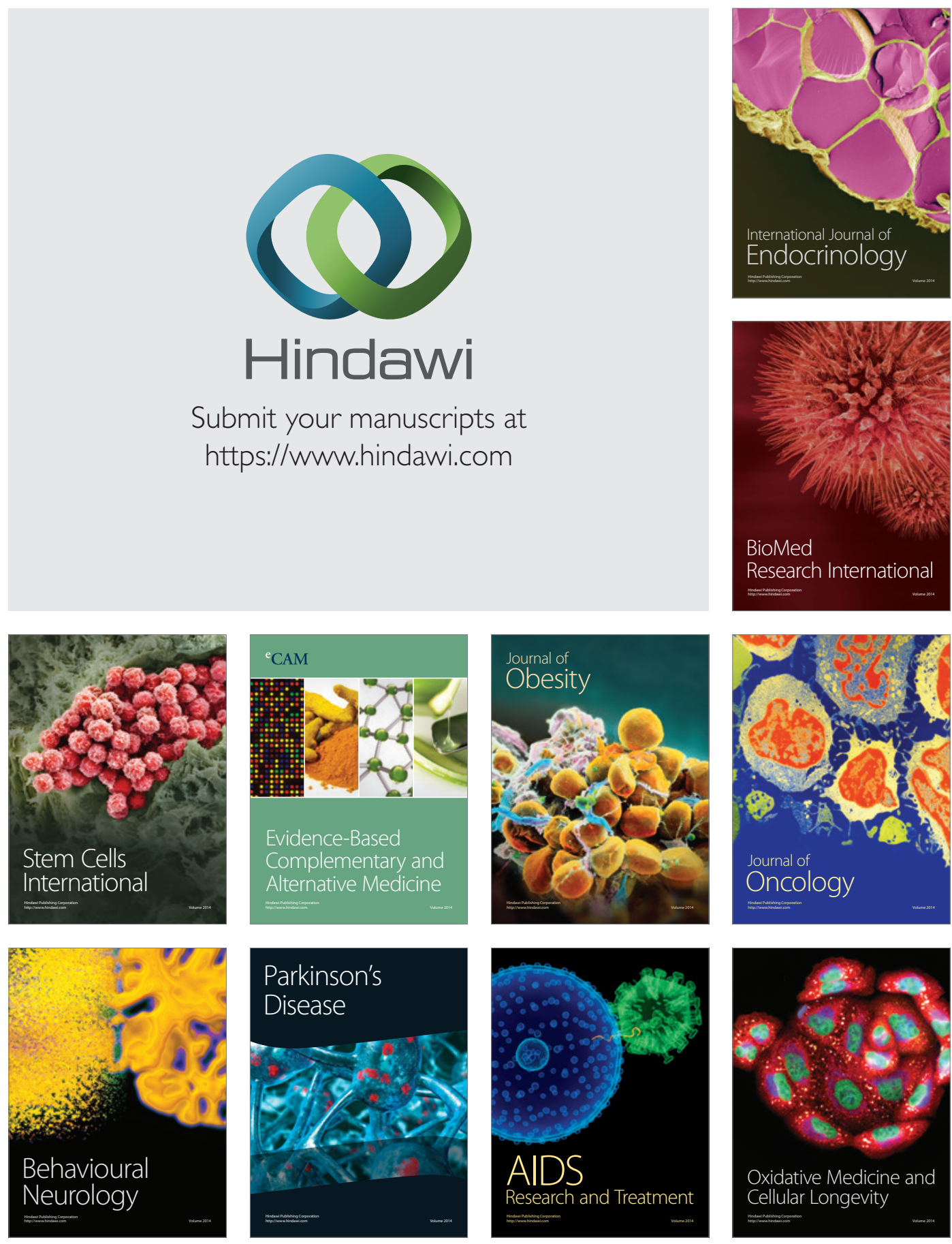